\title{
Què hi ha en un like? Continguts polítics en Facebook i Instagram en les eleccions autonòmiques valencianes de 2019*
}

\author{
Silvia Marcos García
}

UNIVERSITAT JAUME I DE CASTELĹ́

smarcos@auji.es

ORCID: 0000-0003-1682-1009

Nadia Viounnikoff-Benet

UNIVERSITAT JAUME I DE CASTELLÓ

nbenet/िuji.es

ORCID: 0000-0001-6741-9728

\section{Andreu Casero Ripollés}

UNIVERSITAT JAUME I DE CASTELLó

casero\&uji.es

ORCID: 0000-0001-6986-4163

Rebut: 14/10/2019

Acceptat: 20/03/2020

RESUM

En els últims anys, xarxes socials com Facebook i Instagram s'han situat com els espais preferents de la comunicació política. D'una banda, els actors polítics han incorporat aquestes xarxes a la seua estratègia com un canal a través del qual compartir els seus missatges. D'altra banda, els usuaris hi troben un espai on participar i mostrar el seu interés per diferents qüestions polítiques. L'objectiu d'aquesta investigació és analitzar les publicacions difoses en Facebook i Instagram per part dels principals partits polítics valencians i els líders respectius en campanya electoral per tal de saber quines característiques tenen els continguts que més atenció han generat en els usuaris d'aquestes xarxes socials. Amb aquest objectiu, s'hi examinaran la funció i la temàtica dels posts, la presència de recursos visuals i l'ús d'eines d'interacció en les publicacions amb més likes. Els resultats demostren que la posició que ocupen els actors polítics influeix en l'èxit dels continguts entre el públic d'aquestes xarxes socials. Mentre que els seguidors dels partits en l'oposició prefereixen missatges crítics amb els adversaris polítics, els seguidors dels partits en el Govern són partidaris dels missatges focalitzats en els èxits aconseguits en la gestió. Paral-lelament, els temes centrats en polítiques socials i qüestions de campanya electoral són els que generen més likes entre el públic. Així mateix, la presència de recursos visuals, com fotografies o vídeos, d'una banda, i d'etiquetes i enllaços, de l'altra, afavoreix una reacció positiva dels usuaris.

Paraules clau: comunicació política, campanya electoral, Comunitat Valenciana, xarxes socials, Facebook, Instagram.

\footnotetext{
*Agraïments: aquest treball està vinculat al projecte d'investigació UJI-B2017-55 finançat per la Universitat Jaume I de Castelló dins del Pla de Promoció de la Investigació 2017.
} 
ABSTRACT. What is in a 'Like'? Political content on Facebook and Instagram in the 2019 Valencian regional election

Over the last few years, social networks such as Facebook and Instagram have become the preferred places for political communication. On the one hand, political actors have incorporated them into their strategy as a channel through which they can share their messages. On the other hand, users have a space where they can take part and show their interest in political issues. This paper examines posts on Facebook and Instagram by the main Valencian political parties and their respective leaders in the election campaign. We analysed the nature of the content and users' 'likes' to reveal the functions and themes of the most popular posts and the use made of visual resources and interaction tools. The results show that the position of political actors influences the content with the most 'likes'. While supporters of opposition parties are most pleased by critical messages, followers of pro-government parties prefer messages that focus on management success. At the same time, issues focusing on social policies and election campaign issues are those that generate the most 'likes' among the public. Likewise, both visual aids (such as photographs and videos), and hashtags and links help boost users' approval.

Keywords: political communication, election campaign, Valencian Community, social media, Facebook, Instagram.

\section{SUMARI}

Introducció

Facebook i Instagram com a xarxes socials de referència en la comunicació política

Les xarxes socials com a espai per a la participació de la ciutadania

Les eleccions autonòmiques de la Comunitat Valenciana de 2019

Objectiu.

Metodologia

- Mostra

- Instruments

\section{Resultats}

- Funcions amb més likes entre els usuaris de Facebook i Instagram

- Temes amb més likes entre els usuaris de Facebook i Instagram

- Recursos visuals amb més likes entre els usuaris de Facebook i Instagram

- Recursos d'interacció amb més likes entre els usuaris de Facebook i Instagram

Conclusions

Referències bibliogràfiques

Autor per a correspondència / Corresponding author: Silvia Marcos García. Facultat de Ciències Humanes i Socials. Av. de Vicent Sos Baynat s/n, 12071 Castelló de la Plana.

Citació suggerida / Suggested citation: Marcos García, S. et al. (2020). Què hi ha en un like? Continguts polítics en Facebook i Instagram en les eleccions autonòmiques valencianes de 2019. Debats. Revista de cultura, poder i societat, 134(1), 91-116. DOI: http://doi.org/10.28939/iam.debats.134-1.7 


\section{INTRODUCCIÓ}

En els últims anys, les xarxes socials han aconseguit un paper rellevant en el camp de la comunicació política (Vaccari, 2017; Rúas Araujo i Casero Ripollés, 2018). En aquest context, nombrosos estudis encara observen amb cert escepticisme l'ús de les xarxes socials, argumentant que no han acabat d'institucionalitzar-se i que generen un grau més alt de complexitat en les negociacions polítiques (Mancini, 2013), així com que la repercussió de les activitats i accions digitals en els espais de decisió i gestió política tradicionals és escassa (Morozov, 2011; Christensen i Bengtsson, 2011). No obstant això, altres autors indiquen que les potencialitats comunicatives que tenen aquestes plataformes les han convertides en una eina habitual en les estratègies de comunicació dels actors polítics i en la relació que tenen amb la ciutadania en l'entorn digital (McNair, 2011; Chadwick, 2013; Casero Ripollés et al., 2016). D'una banda, les xarxes socials faciliten que partits i polítics puguen connectar amb l'audiència en línia de manera directa i pròxima, sense necessitat de la intermediació dels mitjans de comunicació (Jenkins, 2006). D’altra banda, en aquest context, els usuaris abandonen el seu rol passiu en el consum d'informació, produint i difonent els seus propis continguts i expressant la seua opinió i els seus interessos lliurement (Díaz, 2014; Micó i Casero Ripollés, 2014).

Xarxes socials com Facebook i Instagram s'han convertit en espais destacats en la comunicació política. Actualment, són dues de les plataformes amb més trànsit d'audiència, que reuneixen més de 2.000 i 1.000 milions d'usuaris actius al mes, respectivament (Hootsuite, 2019). D'igual manera, estudis recents demostren com líders i partits espanyols les han incorporades com una eina habitual en les seues estratègies comunicatives en línia (Abejón et al., 2012; Fenoll i Cano Orón, 2017; Marcos García i Alonso Muñoz, 2017; Selva Ruíz i Caro Castaño, 2017; López Rabadán i Doménech Fabregat, 2018). Segons la literatura prèvia, ambdues plataformes contribueixen a la mobilització electoral, l'autopromoció, la presentació estratè- gica dels candidats i a que hi haja més connexió entre actors polítics i ciutadania (Enli i Skogerbø, 2013; Giansante, 2015; Filimonov et al., 2016). No obstant això, encara es desconeix quin és l'ús que fan els ciutadans d'aquestes xarxes socials, perquè els estudis que s'han dut a terme des de la seua perspectiva encara són escassos.

Amb l'objectiu de proporcionar noves evidències en l'ús de Facebook i Instagram en un àmbit polític, aquest estudi examina, de manera comparativa, el contingut de les publicacions en Facebook i Instagram dels principals partits polítics de la Comunitat Valenciana i els líders respectius durant la campanya de les eleccions a les Corts Valencianes de 2019, així com l'impacte que tenen en el públic. En concret, es pretén conéixer quins continguts hi ha en els posts que han generat més likes entre els usuaris.

Les eleccions autonòmiques de la Comunitat Valenciana se situen en un context singular, a causa - principalment- de l'aparició de noves forces polítiques i la fragmentació dels resultats, que van fer inviable que algun partit aconseguira la majoria absoluta per a poder governar. Aquest escenari polític permet estudiar un període rellevant i d'interés per al camp de la comunicació política.

\section{FACEBOOK I INSTAGRAM COM A XARXES SOCIALS DE REFERÈNCIA EN LA COMUNICACIÓ POLÍTICA}

La incorporació de les eines digitals en l'escenari polític s'ha fet de manera progressiva, de manera que, al llarg d'aquesta última dècada, formacions i polítics s'han vist en la necessitat d'adaptar la seua estratègia comunicativa a les noves dinàmiques en internet (Kreiss, 2012). Actualment, l'ús de recursos digitals per part d'aquests actors s'ha convertit en quelcom natural i quotidià (Stromer Galley, 2014; Lilleker et al., 2015) i s'ha integrat de manera generalitzada en les estratègies de campanya electoral (Castillejo i Semova, 2012; García et al., 2012). 
Des que va començar a utilitzar-se en el camp de la comunicació política, Twitter s'ha considerat una de les xarxes socials de referència en la política virtual (Jungherr, 2014; Kruikemeier, 2014). Com a conseqüència d'això, nombroses investigacions han estudiat els diferents objectius que els actors polítics han perseguit en aquesta plataforma (Rahat i Sheafer, 2007; Parmelee i Bichard, 2011; López Meri et al., 2017), així com les temàtiques principals que hi ha en la xarxa social (Zugasti Azagra i Pérez González, 2016; López García, 2016; Alonso Muñoz i Casero Ripollés, 2018) i l'ús de recursos visuals (Quevedo et al., 2016) o d'interacció (Miquel Segarra et al., 2017).

No obstant això, el gran nombre d'usuaris presents en xarxes socials com Facebook o Instagram fa que aquestes es convertisquen també en espais atractius per als actors polítics. Les formacions i els líders polítics respectius cada vegada utilitzen més aquestes dues plataformes com canals a través dels quals aproximar-se al seu electorat (Abejón et al., 2012; Fenoll i Cano Orón, 2017; Marcos García i Alonso Muñoz, 2017; Selva Ruíz i Caro Castaño, 2017). Un ús que es consolida a partir de les eleccions generals celebrades a Espanya els anys 2015 i 2016 (Abejón Mendoza i Mayoral Sánchez, 2017; Quevedo Redondo i Portalés Oliva, 2017).

Estudis com el de Magin et al. (2017) indiquen que Facebook proporciona un canal de retroalimentació, la qual cosa permet als partits entaular converses amb els electors. Un fet que, sumat a la capacitat d'aquesta xarxa social per a la creació i l'organització de comunitats (Casero Ripollés, 2018), possibilita fomentar la participació política (Di Bonito, 2014). De la mateixa manera, les múltiples aplicacions que té permeten potenciar la disseminació d'informació electoral (Magin et al., 2017) i l'autopromoció dels actors polítics (Enli i Skogerbø, 2013), alhora que es fomenta una relació pròxima amb la ciutadania (Giansante, 2015). Investigacions recents indiquen, a més, que la incorporació el 2016 de nous recursos d'interacció perquè els usuaris puguen compartir la seua sorpresa, tristesa o enuig, entre d'altres, davant d'un contingut, fan de Facebook un mecanisme útil per a conéixer més de prop les emocions de l'electorat (Coromina et al., 2018).

Per la seua part, Instagram ha impulsat un canvi en l'ús de les xarxes socials, de manera que elements visuals habituals en aquesta xarxa, com imatges, vídeos o emoticones, són recursos cada vegada més presents en les estratègies comunicatives dels usuaris (Svensson i Russmann, 2017).

La incorporació d'aquests recursos com a base de l'estratègia comunicativa està impulsant noves dinàmiques basades en la personalització (Enli i Skogerbø, 2013; Bentivegna, 2015; López Rabadán i Doménech Fabregat, 2018). En particular, l'ús individualitzat d'Instagram permet potenciar la construcció d'una imatge més espontània i humana del líder polític, així com una aproximació més personal amb els usuaris (Selva Ruíz i Caro Castaño, 2017; Viounnikoff-Benet, 2018).

Com a conseqüència d'aquestes possibilitats, els principals estudis efectuats entorn d'aquestes xarxes socials s'han centrat en l'anàlisi dels diferents usos que els actors polítics fan d'aquestes plataformes dins de la seua estratègia comunicativa. No obstant això, malgrat que alguns autors han advertit la importància del rol dels ciutadans i ciutadanes en aquestes plataformes (Fenoll i Cano Orón, 2017; Coromina et al., 2018), les investigacions sobre aquest tema encara són limitades.

\section{LES XARXES SOCIALS COM A ESPAI PER A LA PARTICIPACIÓ DE LA CIUTADANIA}

Una de les potencialitats més significatives que han incorporat les xarxes socials és la possibilitat que els ciutadans participen lliurement en el debat polític. Aquestes plataformes digitals transformen el paper passiu que mantenien fins ara i converteixen els usuaris en creadors actius de continguts amb capacitat per a expressar la seua opinió i el seu interés sobre les diferents qüestions polítiques (Jenkins 2006; Micó i Casero Ripollés, 2014). 
Eines pròpies d'aquestes plataformes —com les mencions(@)_- afavoreixen significativament el desenvolupament de noves vies de contacte entre usuaris, de manera que aquests poden respondre directament a les preguntes plantejades per un determinat perfil o mantindre una conversa (Larsson, 2015). No obstant això, investigacions anteriors han demostrat que l'ús d'aquesta mena de recurs en el debat polític és limitat, tant per part dels actors polítics com per part de la ciutadania (Alonso Muñoz et al., 2016; Marcos García et al., 2017).

Tanmateix hi ha altres tipus de recursos d'interactivitat selectiva que, malgrat no fomentar la conversa entre usuaris, sí que possibiliten una interacció directa amb els continguts, de manera que mostren quins són els gustos o interessos dels usuaris (Miquel Segarra et al., 2017). En aquest context, els m'agrada (likes) o l'opció de compartir, recursos presents tant en Facebook com en Instagram, permeten expressar l'adhesió i acceptació davant dels continguts publicats per altres perfils, així com reafirmar l'interés per determinades publicacions (Larsson, 2015; Coromina et al., 2018).

Fins ara, els estudis sobre aquest tema demostren que els partits polítics utilitzen sovint els recursos visuals -especialment les fotografies- (Fenoll i Hassler, 2019), ja que un dels elements que genera més atenció entre els usuaris són les imatges (Viounnikoff-Benet, 2018). De la mateixa manera, un altre dels recursos que repercuteixen en una interacció notable són els enllaços (Miquel Segarra et al., 2017). Tanmateix, a penes es coneixen més detalls sobre quin tipus de missatges o continguts han generat més repercussió en els usuaris.

\section{LES ELECCIONS AUTONÒMIQUES DE LA COMUNITAT VALENCIANA DE 2019}

Els estudis a Espanya sobre xarxes socials i campanyes electorals s'han centrat en gran part en les eleccions estatals. Per contra, les investigacions d'aquest tipus que examinen altres processos polítics, com les eleccions autonòmiques, municipals o europees, són encara limitades. Resulten rellevants, no obstant això, les anàlisis sobre les eleccions basques de 2009 i 2012 (Cebrián Guinovart et al., 2013; Pérez et al. 2014); les eleccions madrilenyes de 2011 o 2015 (Fernández Muñoz i Arceo Vacas, 2015; Marcos García i Alonso Muñoz, 2019) o les catalanes de 2010, 2011 o 2015 (Di Bonito, 2014; López Meri, 2016). En el cas de la Comunitat Valenciana, destaquen especialment els estudis de Gamir Ríos (2016) o López García et al. (2016) sobre Twitter i l'establiment d'una agenda temàtica.

Les eleccions autonòmiques de la Comunitat Valenciana celebrades el 28 d'abril de 2019 es van situar en un context singular, principalment a causa de l'aparició de noves forces polítiques i de la gran fragmentació dels resultats. D'una banda, a la presència de dues forces emergents en les eleccions autonòmiques anteriors, de 2015, Unides Podem i Ciudadanos, es va sumar la irrupció recent de Vox. D'altra banda, el gran nombre de candidatures va derivar en el fet que cap partit aconseguira la majoria absoluta, la qual cosa va iniciar un període de negociacions amb la finalitat d'establir un pacte de Govern com ja havia ocorregut en les eleccions a les Corts Valencianes de 2015.

\section{OBJECTIU}

L'objectiu d'aquesta investigació és analitzar les publicacions que han fet en Facebook i Instagram els principals partits polítics de la Comunitat Valenciana i els líders respectius per saber quines característiques tenen i quins elements estan presents en els missatges que han obtingut més likes dels usuaris. En concret, es formulen les preguntes d'investigació següents:

PI1: Quines funcions compleixen, quins temes tracten i quins recursos visuals i d'interacció inclouen les publicacions dels actors polítics que han obtingut més likes? 
PI2: La quantitat de likes aconseguida en les publicacions està condicionada per l'eix ideològic progressista o conservador, la trajectòria tradicional o emergent o la posició en el Govern o en l'oposició dels actors polítics analitzats?

\section{METODOLOGIA}

\section{Mostra}

La mostra d'aquesta investigació es va extraure en la campanya de les eleccions a les Corts Valencianes celebrades el 28 d'abril de 2019 i se centra en els perfils de Facebook i Instagram dels sis partits polítics principals de la Comunitat Valenciana: Partit Popular (PP), Partit Socialista (PSPV-PSOE), Compromís, Unides Podem, Ciudadanos (Cs) i Vox; i els candidats $\mathrm{i}$ candidates respectius, Isabel Bonig, Ximo Puig, Mónica Oltra, Rubén M. Dalmau i Toni Cantó. El candidat de Vox, José María Llanos, no s’ha inclòs en l'anàlisi perquè no té cap publicació en Facebook i només en té una en Instagram durant el període seleccionat. S'analitzen els quinze dies oficials de campanya, el dia de reflexió, el dia de les eleccions i el dia posterior a aquestes.

Concretament, el corpus de l'estudi està format per les publicacions en Facebook i en Instagram que han obtingut un nombre de m'agrada per damunt de la mitjana de cadascun dels perfils dels actors polítics seleccionats. L'elecció de la quantitat de likes com a base per a la inclusió de les publicacions en la mostra s'ha fet tenint en compte que aquest recurs és comú en ambdues xarxes socials. Així mateix, aquest complement és el més senzill i també el que més utilitzen els usuaris per a mostrar el seu interés per aquelles publicacions que els han cridat més l'atenció (Larsson, 2015; Corominaet al., 2018). D'aquesta manera, l'estudi d'aquests missatges permet conéixer quines característiques i elements són els més habituals en les publicacions que han generat més likes entre els usuaris. Així, del total de 1.027 publicacions compartides pels sis partits i els candidats respectius en Facebook i
Instagram durant els díhuit dies analitzats, aquesta investigació n'examina 347, que representen un $33,78 \%$ de la mostra total (Taula 1 ).

La selecció dels partits polítics de la mostra s'ha realitzat sobre la base de dos criteris: la representativitat i la trajectòria històrica. D'una banda, són els sis partits que van obtindre la major part dels vots en les eleccions, ja que en conjunt en van acumular el 95,43 \%. D'altra banda, mentre que el PP, el PSPV-PSOE i Compromís són tres de les formacions amb més tradició política en aquesta comunitat autònoma, Unides Podem, Cs i Vox són tres formacions emergents. Resulta especialment rellevant el cas d'aquesta última, que no tenia representació prèvia en les Corts Valencianes. Aquesta elecció permet comparar l'estratègia plantejada per partits i líders tradicionals amb altres d'aparició recent en el mapa polític autonòmic.

\section{Instruments}

Per respondre l'objectiu d'aquesta investigació i les preguntes plantejades, s'aplica una metodologia basada en l'anàlisi de contingut quantitatiu, el qual ens permet oferir una anàlisi descriptiva — de manera objectiva i sistemàtica (Igartua, 2006) - de les característiques i els elements presents en les publicacions amb més likes. Dos codificadors han analitzat manualment les publicacions d'ambdues xarxes socials, de manera que el grau de fiabilitat intercodificadors aconseguit és de 0,98, segons el coeficient Pi de Scott.

Per a l'aplicació d'aquest, s'ha elaborat un model d'anàlisi específic i s'ha adaptat a l'objecte d'estudi, dividit en dos grans nivells.

En el primer nivell s'estudia la funció i la temàtica dels missatges publicats pels actors polítics (Taula 2).

En un segon nivell, s'analitza l'ús de recursos visuals segons la tipologia, el context i l'element o els elements protagonistes. Es posa també el focus en els recursos d'interacció propis que ofereixen tant 
Tabla 1 Nombre de publicacions seleccionades per perfil en cada xarxa social

\begin{tabular}{|c|c|c|c|c|c|c|}
\hline \multirow{3}{*}{$\begin{array}{l}\text { Perfil } \\
\qquad \text { PP }\end{array}$} & \multicolumn{2}{|c|}{$\begin{array}{l}\text { Nre. total de } \\
\text { publicacions }\end{array}$} & \multicolumn{2}{|c|}{$\begin{array}{l}\text { Mitjana de likes. } \\
\text { (nre. total de likes / nre. } \\
\text { total de publicacions per } \\
\text { perfil) }\end{array}$} & \multicolumn{2}{|c|}{$\begin{array}{l}\text { Nre. de publicacions amb } \\
\text { likes per damunt de la } \\
\text { mitjana }\end{array}$} \\
\hline & $\mathrm{FB}$ & IG & $\mathrm{FB}$ & IG & $\mathrm{FB}$ & IG \\
\hline & 66 & 29 & 30,33 & 64 & 26 & 12 \\
\hline \multirow[t]{2}{*}{ PSPV-PSOE } & $\mathrm{FB}$ & IG & $\mathrm{FB}$ & IG & $\mathrm{FB}$ & IG \\
\hline & 61 & 39 & 204,88 & 114 & 22 & 17 \\
\hline \multirow[t]{2}{*}{ Compromís } & $\mathrm{FB}$ & $I G$ & $\mathrm{FB}$ & IG & $\mathrm{FB}$ & IG \\
\hline & 68 & 51 & 476,38 & 636 & 21 & 21 \\
\hline \multirow[t]{2}{*}{ Unides Podem } & $\mathrm{FB}$ & IG & $\mathrm{FB}$ & IG & FB & IG \\
\hline & 78 & 36 & 86,57 & 109 & 14 & 12 \\
\hline \multirow[t]{2}{*}{ Cs } & FB & IG & $\mathrm{FB}$ & IG & FB & $I G$ \\
\hline & 40 & 20 & 68,32 & 110 & 11 & 7 \\
\hline \multirow[t]{2}{*}{ Vox } & $\mathrm{FB}$ & $I G$ & $\mathrm{FB}$ & IG & $\mathrm{FB}$ & $\mathrm{IG}$ \\
\hline & 76 & 35 & 213,96 & 591 & 32 & 14 \\
\hline \multirow[t]{2}{*}{ Bonig } & $\mathrm{FB}$ & IG & $\mathrm{FB}$ & IG & $\mathrm{FB}$ & IG \\
\hline & 77 & 39 & 67,94 & 214 & 21 & 17 \\
\hline \multirow[t]{2}{*}{ Puig } & $\mathrm{FB}$ & IG & FB & $I G$ & FB & $I G$ \\
\hline & 63 & 32 & 170,22 & 195 & 15 & 10 \\
\hline \multirow[t]{2}{*}{ Oltra } & $\mathrm{FB}$ & IG & $\mathrm{FB}$ & IG & $\mathrm{FB}$ & IG \\
\hline & 49 & 27 & 562,53 & 963 & 19 & 7 \\
\hline \multirow[t]{2}{*}{ Dalmau } & $\mathrm{FB}$ & IG & $\mathrm{FB}$ & IG & $\mathrm{FB}$ & IG \\
\hline & 75 & 15 & 162,13 & 80 & 28 & 7 \\
\hline \multirow[t]{2}{*}{ Cantó } & $\mathrm{FB}$ & $I G$ & $\mathrm{FB}$ & $I G$ & $\mathrm{FB}$ & $I G$ \\
\hline & & 9 & 225,71 & 613 & 11 & 3 \\
\hline \multicolumn{5}{|c|}{ TOTAL per xarxa } & 220 & 127 \\
\hline \multicolumn{5}{|c|}{ TOTAL publicacions analitzades } & \multicolumn{2}{|c|}{347} \\
\hline
\end{tabular}


Taula 2 Protocol d'anàlisi de funcions i temes

\begin{tabular}{|c|c|c|c|}
\hline \multicolumn{2}{|r|}{ Funció } & \multicolumn{2}{|r|}{ Tema } \\
\hline Agenda & $\begin{array}{l}\text { Publicacions amb informació sobre } \\
\text { actes de campanya concrets. }\end{array}$ & Economia & $\begin{array}{l}\text { Publicacions sobre ocupació, atur, } \\
\text { salaris, dèficit, despesa pública, } \\
\text { deute, crisi, impostos, emprenedoria, } \\
\text { etc. }\end{array}$ \\
\hline $\begin{array}{l}\text { Programa o } \\
\text { promeses }\end{array}$ & $\begin{array}{l}\text { Publicacions amb propostes progra- } \\
\text { màtiques i de futur, així com desitjos } \\
\text { o valoracions en relació amb el seu } \\
\text { projecte de Govern. }\end{array}$ & Política social & $\begin{array}{l}\text { Publicacions sobre pensions, sanitat, } \\
\text { educació, estat del benestar, justícia } \\
\text { social, igualtat, immigració, etc. }\end{array}$ \\
\hline $\begin{array}{l}\text { Assoliments } \\
\text { polítics de } \\
\text { gestió o } \\
\text { oposició }\end{array}$ & $\begin{array}{l}\text { Publicacions que enalteixen o lloen } \\
\text { els assoliments aconseguits pel } \\
\text { partit o líder. }\end{array}$ & $\begin{array}{l}\text { Cultura i } \\
\text { esport }\end{array}$ & $\begin{array}{l}\text { Publicacions sobre indústries cul- } \\
\text { turals (cinema, literatura, art, etc.) i } \\
\text { esport. }\end{array}$ \\
\hline $\begin{array}{l}\text { Crítica a } \\
\text { l'adversari }\end{array}$ & $\begin{array}{l}\text { Publicacions amb atacs explícits } \\
\text { a adversaris, així com als projec- } \\
\text { tes polítics, accions o ideologies } \\
\text { d'aquests. }\end{array}$ & $\begin{array}{l}\text { Ciència i } \\
\text { tecnologia }\end{array}$ & $\begin{array}{l}\text { Publicacions sobre } R+D+i \text {, infraes- } \\
\text { tructura de xarxes de dades (fibra } \\
\text { òptica, ADSL, wifi), etc. }\end{array}$ \\
\hline $\begin{array}{l}\text { Informació } \\
\text { mediàtica }\end{array}$ & $\begin{array}{l}\text { Publicacions que comparteixen } \\
\text { contingut mediàtic protagonitzat pel } \\
\text { partit o líder. }\end{array}$ & $\begin{array}{l}\text { Infraestruc- } \\
\text { tures }\end{array}$ & $\begin{array}{l}\text { Publicacions sobre serveis de } \\
\text { transport i infraestructures, com per } \\
\text { exemple carreteres. }\end{array}$ \\
\hline Interacció & $\begin{array}{l}\text { Publicacions on el partit o líder res- } \\
\text { pon a un usuari o on es planteja una } \\
\text { qüestió als seguidors. }\end{array}$ & Corrupció & $\begin{array}{l}\text { Publicacions sobre corrupció política } \\
\text { o empresarial. }\end{array}$ \\
\hline Participació & $\begin{array}{l}\text { Publicacions que apel-len directa- } \\
\text { ment al vot, a la petició de donatius } \\
\text { econòmics i a la mobilització de } \\
\text { voluntaris. }\end{array}$ & $\begin{array}{l}\text { Regeneració } \\
\text { democràtica }\end{array}$ & $\begin{array}{l}\text { Publicacions que aborden la neces- } \\
\text { sitat de renovar o eliminar aspectes } \\
\text { democràtics o de la llei electoral; } \\
\text { missatges sobre franquisme, } \\
\text { memòria històrica, defensa de la } \\
\text { constitució, estat de dret i separació } \\
\text { de poders. }\end{array}$ \\
\hline $\begin{array}{l}\text { Comunitat: } \\
\text { valors/ } \\
\text { ideologia }\end{array}$ & $\begin{array}{l}\text { Publicacions que reforcen els valors } \\
\text { o ideologia del partit/líder. Apel·len a } \\
\text { les emocions per a generar imatge } \\
\text { d'unió i aproximar-se als usuaris } \\
\text { que s'identifiquen amb aquests } \\
\text { valors. }\end{array}$ & $\begin{array}{l}\text { Joc i estratègia } \\
\text { política }\end{array}$ & $\begin{array}{l}\text { Publicacions centrades en la inten- } \\
\text { ció dels actors polítics de construir } \\
\text { un determinat tipus de govern o so- } \\
\text { bre possibles (o impossibles) futurs } \\
\text { pactes de govern. }\end{array}$ \\
\hline $\begin{array}{l}\text { Comunitat: } \\
\text { vida personal/ } \\
\text { backstage }\end{array}$ & $\begin{array}{l}\text { Publicacions en què els partits o } \\
\text { líders mostren una actitud més } \\
\text { humana i personal. Comparteixen } \\
\text { assumptes de la vida privada (oci, } \\
\text { aficions, esport, etc.). }\end{array}$ & $\begin{array}{l}\text { Votació i } \\
\text { resultats } \\
\text { electorals }\end{array}$ & $\begin{array}{l}\text { Publicacions centrades en la votació, } \\
\text { els resultats electorals i les enques- } \\
\text { tes i sondejos. }\end{array}$ \\
\hline $\begin{array}{l}\text { Comunitat: } \\
\text { diversió }\end{array}$ & $\begin{array}{l}\text { Publicacions en les quals es busca } \\
\text { entretindre i divertir els usuaris. }\end{array}$ & $\begin{array}{l}\text { Model } \\
\text { territorial de } \\
\text { l'Estat }\end{array}$ & $\begin{array}{l}\text { Publicacions relacionades amb } \\
\text { l'organització territorial de l'Estat } \\
\text { espanyol. }\end{array}$ \\
\hline
\end{tabular}




\begin{tabular}{|c|c|c|c|}
\hline \multicolumn{2}{|r|}{ Funció } & \multicolumn{2}{|r|}{ Tema } \\
\hline Humor & $\begin{array}{l}\text { Publicacions en les quals es com- } \\
\text { parteixen acudits, mems, etc. }\end{array}$ & Terrorisme & $\begin{array}{l}\text { Publicacions relacionades amb el te- } \\
\text { rrorisme en totes les seues formes. }\end{array}$ \\
\hline $\begin{array}{l}\text { Missatges } \\
\text { de cortesia/ } \\
\text { protocol }\end{array}$ & $\begin{array}{l}\text { Publicacions de cortesia, amb mis- } \\
\text { satges d'agraïment, condol, saluta- } \\
\text { cions, etc. }\end{array}$ & $\begin{array}{l}\text { Temes } \\
\text { personals }\end{array}$ & $\begin{array}{l}\text { Publicacions que fan referència a } \\
\text { qüestions de la vida personal dels } \\
\text { actors polítics. }\end{array}$ \\
\hline Altres & $\begin{array}{l}\text { Publicacions que no es poden classi- } \\
\text { ficar en les categories anteriors. }\end{array}$ & $\begin{array}{l}\text { Organització } \\
\text { de campanya }\end{array}$ & $\begin{array}{l}\text { Publicacions que conten com } \\
\text { s'organitzen els diferents actes de } \\
\text { campanya com per exemple mítings, } \\
\text { visites, trobades, etc. }\end{array}$ \\
\hline & & $\begin{array}{l}\text { Relació amb } \\
\text { els mitjans de } \\
\text { comunicació }\end{array}$ & $\begin{array}{l}\text { Publicacions que comparteixen } \\
\text { informació sobre intervencions } \\
\text { dels actors polítics en mitjans de } \\
\text { comunicació. }\end{array}$ \\
\hline & & Sense tema & $\begin{array}{l}\text { Publicacions composades per emo- } \\
\text { ticones o per una o poques paraules, } \\
\text { que no es corresponen amb cap } \\
\text { tema específic i en els quals és } \\
\text { difícil deduir quina qüestió estan } \\
\text { tractant. }\end{array}$ \\
\hline & & Afers exteriors & $\begin{array}{l}\text { Publicacions centrades en la Unió } \\
\text { Europea i altres parts del món. }\end{array}$ \\
\hline & & Arenga política & $\begin{array}{l}\text { Publicacions similars als eslògans } \\
\text { de campanya. }\end{array}$ \\
\hline & & Medi ambient & $\begin{array}{l}\text { Publicacions sobre contaminació, } \\
\text { protecció de la fauna i flora o el } \\
\text { canvi climàtic. }\end{array}$ \\
\hline & & Altres & $\begin{array}{l}\text { Publicacions que no es poden classi- } \\
\text { ficar en les categories anteriors. }\end{array}$ \\
\hline
\end{tabular}

Font: Elaboració pròpia.

Facebook com Instagram: les mencions, els hashtags i els enllaços (Taula 3 ).

\section{Resultats}

L'anàlisi de les publicacions seleccionades en aquest estudi ens permet identificar diverses tendències en les funcions, les temàtiques i els recursos visuals i d'interacció de les publicacions de partits i líders polítics que més likes han generat en Facebook i Instagram.

\section{Funcions amb més likes entre els usuaris de Facebook i Instagram}

Si centrem l'anàlisi en la funció de la publicació, les dades assenyalen que les que més likes tenen estan directament condicionades per la posició que ocupa el partit o el candidat en el Govern. En el cas dels actors polítics de l'oposició (PP, Cs i Vox), s'observa que els missatges que han generat més m'agrada en Facebook entre els usuaris tenen la funció principal 
Taula 3 Protocol d'anàlisi de recursos visuals

\begin{tabular}{|c|c|c|}
\hline \multicolumn{3}{|c|}{ Recursos visuals } \\
\hline \multirow[t]{8}{*}{ Tipus de recurs } & \multicolumn{2}{|l|}{ Fotografia } \\
\hline & \multicolumn{2}{|l|}{ Selfie } \\
\hline & \multicolumn{2}{|l|}{ Muntatge } \\
\hline & \multicolumn{2}{|c|}{ Mem o vinyeta } \\
\hline & \multicolumn{2}{|l|}{ Vídeo } \\
\hline & \multicolumn{2}{|l|}{ GIF } \\
\hline & \multicolumn{2}{|c|}{ Cartell/pòster } \\
\hline & \multicolumn{2}{|l|}{ Gràfic } \\
\hline \multirow[t]{11}{*}{ Context } & \multirow{3}{*}{ Personal } & Família: amb familiars o amics. \\
\hline & & Oci: practicant activitats d'oci. \\
\hline & & Backstage: imatges del backstage de la campanya. \\
\hline & \multirow{5}{*}{ Electoral } & Míting: líder o altres polítics o polítiques oferint un míting. \\
\hline & & Visita oficial: líder o altres polítics o polítiques durant una visita oficial. \\
\hline & & Debat: líder o altres polítics o polítiques durant el debat de campanya. \\
\hline & & Espot: imatges d'espots de campanya. \\
\hline & & Votació: líder o altres polítics o polítiques votant en les urnes. \\
\hline & \multirow{3}{*}{ Mediàtic } & Entrevista: líder o altres polítics o polítiques oferint una entrevista. \\
\hline & & $\begin{array}{l}\text { Roda de prensa: líder o altres polítics o polítiques oferint una roda de premsa } \\
\text { als mitjans de comunicació. }\end{array}$ \\
\hline & & In situ: líder o altres polítics o polítiques atenent els mitjans de comunicació. \\
\hline \multirow[t]{15}{*}{ Protagonista } & \multicolumn{2}{|r|}{ ] } \\
\hline & \multicolumn{2}{|c|}{ Líder i membres de la seua formació. } \\
\hline & \multicolumn{2}{|c|}{ Líder i membres d'altres partits. } \\
\hline & \multicolumn{2}{|c|}{ Líder davant de la ciutadania (ex. míting). } \\
\hline & \multicolumn{2}{|c|}{ Líder amb la ciutadania (ex. posant junts, donant-se la mà, etc.). } \\
\hline & \multicolumn{2}{|c|}{ Líder i periodistes/mitjans de comunicació. } \\
\hline & \multicolumn{2}{|c|}{ Líder i personalitats alienes a la política (esportistes, músics, escriptors, etc.). } \\
\hline & \multicolumn{2}{|c|}{ Líder i membres de la seua formació no polítics (cap de premsa, voluntaris, etc.). } \\
\hline & \multicolumn{2}{|c|}{ Líder i familiars o amics. } \\
\hline & \multicolumn{2}{|c|}{ Polítics o polítiques del partit diferents al líder. } \\
\hline & \multicolumn{2}{|c|}{ Polítics o polítiques del partit diferents al líder amb la ciutadania. } \\
\hline & \multicolumn{2}{|c|}{ Polítics o polítiques del partit diferents al líder amb periodistes o mitjans de comunicació. } \\
\hline & \multicolumn{2}{|c|}{ Polítics o polítiques del partit diferents al líder i personalitats alienes a la política. } \\
\hline & \multicolumn{2}{|c|}{$\begin{array}{l}\text { Polítics o polítiques del partit diferents al líder amb membres de la seua formació no polí- } \\
\text { tics. }\end{array}$} \\
\hline & \multicolumn{2}{|c|}{ Sense personatge (paisatges, objectes, etc.). } \\
\hline
\end{tabular}


de criticar als adversaris, especialment si la crítica està dirigida als partits i els candidats que ocupen el Govern (Taula 3). En concret, aquesta funció és la que ha obtingut més likes en els perfils del PP (42,31\%), Isabel Bonig (38,10 \%) i Toni Cantó (45,45 \%), i la segona en els perfils de Ciudadanos $(27,27 \%)$ i Vox $(18,75 \%)$. En aquests dos últims perfils, les publicacions amb més likes són les que comparteixen aspectes d'agenda i informació sobre diferents actes de campanya, en el cas de Vox (25\%) i promeses electorals, en el cas de Ciudadanos (45,4\%) (Taula 4).

Tanmateix, aquest patró no es repeteix en Instagram, on els usuaris mostren interessos dispars (Taula 4).
Els seguidors de Vox $(42,86 \%)$ i del PP (41,67 \%) destinen pràcticament la meitat dels likes a les publicacions que tenen com a propòsit informar de l'agenda d'actes, visites o altres esdeveniments de campanya. En el cas d'Isabel Bonig, les publicacions que generen més likes entre els usuaris són aquelles en què la candidata comparteix propostes del seu programa electoral.

Les dades són desiguals en els perfils de Ciudadanos i del seu líder, Toni Cantó. Els seguidors del partit s’han interessat principalment per aquelles publicacions en què, d'una banda, s'agraeix o es mostra un gest de cortesia enfront d'una persona o esdeveniment

Taula 4 Funcions de les publicacions en Facebook (en \%)

\begin{tabular}{|c|c|c|c|c|c|c|c|c|c|c|c|}
\hline Funció & PP & Bonig & $\begin{array}{l}\text { PSPV- } \\
\text { PSOE }\end{array}$ & Puig & Compr. & Oltra & $\begin{array}{l}\text { Unides } \\
\text { Podem }\end{array}$ & Dalmau & Cs & Cantó & Vox \\
\hline Agenda & 7,69 & - & 31,82 & 6,67 & 4,76 & 21,05 & - & 10,71 & - & - & 25 \\
\hline $\begin{array}{l}\text { Programa o } \\
\text { promeses }\end{array}$ & 11,54 & 9,52 & 13,64 & 26,7 & 9,52 & 21,05 & 7,14 & 3,57 & 45,4 & - & 12,5 \\
\hline $\begin{array}{l}\text { Assoliments polítics } \\
\text { de gestió/oposició }\end{array}$ & 15,38 & 9,52 & 18,18 & 20 & 4,76 & 15,79 & 7,14 & 3,57 & 9,09 & - & - \\
\hline Crítica a l'adversari & 42,31 & 38,10 & 4,55 & 13,3 & 28,57 & 10,53 & - & 10,71 & 27,3 & 45,45 & 18,7 \\
\hline $\begin{array}{l}\text { Informació } \\
\text { mediàtica }\end{array}$ & 11,54 & 9,52 & - & - & - & - & 7,14 & - & - & - & 6,25 \\
\hline Interacció & - & - & - & - & - & - & - & - & - & - & - \\
\hline Participació & 7,69 & 9,52 & 13,64 & 20 & - & 15,79 & 21,43 & 32,14 & 9,09 & - & 9,37 \\
\hline $\begin{array}{l}\text { Comunitat: valors/ } \\
\text { ideologia }\end{array}$ & - & 9,52 & 9,09 & 6,67 & 38,10 & 15,79 & 42,86 & 10,71 & - & 9,09 & 6,25 \\
\hline $\begin{array}{l}\text { Comunitat: vida } \\
\text { personal/backstage }\end{array}$ & - & 4,76 & - & - & - & - & 7,14 & 7,14 & - & 9,09 & 3,12 \\
\hline $\begin{array}{l}\text { Comunitat: } \\
\text { entreteniment. }\end{array}$ & - & - & - & - & 4,76 & - & - & - & - & - & 3,12 \\
\hline Humor & - & - & - & - & - & - & - & - & - & - & 3,12 \\
\hline $\begin{array}{l}\text { Missatges de } \\
\text { cortesia/protocol }\end{array}$ & 3,85 & 9,52 & 4,55 & 6,67 & 9,52 & - & 7,14 & 21,43 & - & 27,27 & 6,25 \\
\hline Altres & - & - & 4,55 & - & - & - & - & - & 9,09 & 9,09 & 6,25 \\
\hline
\end{tabular}


determinat $(42,85 \%)$ i, de l'altra, es busca la participació de l'electorat, apel-lant directament al vot o demanant-los assistir als actes electorals (28,57 \%). En el cas de Cantó, els usuaris també han destinat gran part dels likes a les publicacions en què la funció principal és la participació i la cortesia, així com la d'oferir aspectes relacionats amb la seua vida personal o del backstage de campanya (33,33\% en tots els casos) (Taula 5).

D'aquesta manera, mentre que els seguidors en Instagram del PP, Vox i Bonig s'interessen principalment per qüestions relacionades amb l'esdevenir de la campanya electoral, com ara l'agenda o el progra- ma electoral, els seguidors de Ciudadanos i Cantó es mostren més atrets per continguts orientats a crear una relació més directa i pròxima amb ells.

Quant als partits en el Govern, les dades revelen que no hi ha diferències rellevants en les reaccions dels usuaris de les dues xarxes socials. En totes dues plataformes, la funció que ha generat més likes és la de participació, tant en els perfils dels partits com en el cas dels líders. L'única excepció es troba en el perfil de Facebook de Compromís (Taula 4), en què els seguidors no han mostrat el seu grat pels continguts que exploten aquesta funció.

Taula 5 Funcions de les publicacions en Instagram (en \%)

\begin{tabular}{|c|c|c|c|c|c|c|c|c|c|c|c|}
\hline Funció & PP & Bonig & $\begin{array}{l}\text { PSPV- } \\
\text { PSOE }\end{array}$ & Puig & Compr. & Oltra & $\begin{array}{l}\text { Unides } \\
\text { Podem }\end{array}$ & Dalmau & Cs & Cantó & Vox \\
\hline Agenda & 41,67 & 17,65 & 17,65 & 20 & 9,52 & - & 25 & 42,86 & - & - & 42,9 \\
\hline $\begin{array}{l}\text { Programa } \\
\text { o promeses }\end{array}$ & 25 & 52,94 & 11,76 & 30 & 28,57 & - & 8,33 & 14,29 & - & - & 7,14 \\
\hline $\begin{array}{l}\text { Assoliments polítics } \\
\text { de gestió/oposició }\end{array}$ & 8,33 & 5,88 & 5,88 & 10 & 9,52 & 14,29 & - & - & 14,3 & - & - \\
\hline Crítica a l'adversari & 16,67 & 5,88 & - & - & 9,52 & - & 8,33 & - & - & - & 14,3 \\
\hline $\begin{array}{l}\text { Informació } \\
\text { mediàtica }\end{array}$ & - & - & 5,88 & - & - & - & - & - & - & - & - \\
\hline Interacció & - & - & - & - & - & - & - & - & - & - & - \\
\hline Participació & - & 5,88 & 23,53 & 20 & 19,05 & 57,14 & 16,67 & 28,57 & 28,6 & 33,33 & 14,3 \\
\hline $\begin{array}{l}\text { Comunitat: valors/ } \\
\text { ideologia }\end{array}$ & 8,33 & 11,76 & 35,29 & 10 & 14,29 & 14,29 & 16,67 & - & 14,3 & - & 14,3 \\
\hline $\begin{array}{l}\text { Comunitat: vida } \\
\text { personal/backstage }\end{array}$ & - & - & - & - & - & 14,29 & - & - & - & 33,33 & - \\
\hline $\begin{array}{l}\text { Comunitat: entrete- } \\
\text { niment. }\end{array}$ & - & - & - & - & - & - & - & - & - & - & - \\
\hline Humor & - & - & - & - & - & - & - & - & - & - & - \\
\hline $\begin{array}{l}\text { Missatges de } \\
\text { cortesia/protocol }\end{array}$ & - & - & - & 10 & - & - & 16,67 & - & 42,9 & 33,33 & - \\
\hline Altres & - & - & - & - & 4,76 & - & 8,33 & 14,29 & - & - & 7,14 \\
\hline
\end{tabular}

Font: Elaboració pròpia. 
Una altra de les funcions que més likes reuneix en els continguts dels actors polítics en el Govern és la de «Comunitat: valors/ideologia». Es tracta de publicacions que enalteixen i enforteixen les idees, el posicionament i l'essència del partit amb l'objectiu que els seus seguidors se senten pròxims i identificats amb el projecte polític. Aquesta funció té una rellevància especial en els perfils dels partits polítics, que usen aquest tipus de publicació com una via per a traslladar les idees i les creences col-lectives i crear una comunitat de seguidors fidels als valors del partit. En particular, aquesta funció ha sigut la que més ha agradat en els perfils de Facebook de Compromís $(38,10 \%)$ i Unides Podem $(42,86 \%)$ i en el d'Instagram del PSPV-PSOE (35,19 \%).

Les funcions d' «Agenda» $\mathrm{i}$ «Programa o promeses» (taules 4 i 5) aconsegueixen un nombre de likes similar al de «Comunitat: valors/ideologia». D'aquesta manera es demostra que, tot i que els seguidors se senten interessats per les publicacions en què els actors polítics busquen acostar-se al seu electorat, també destinen una part considerable dels likes a les publicacions sobre qüestions directament relacionades amb la campanya, com ara els actes o el programa electoral. Així, tant una funció com l'altra es troben indistintament en perfils de partits i líders en el Govern. No obstant això, es pot destacar el cas de Puig, els seguidors del qual han reaccionat en Facebook $(26,7 \%)$ i Instagram (30 \%) principalment a aquelles publicacions on el president de la Generalitat Valenciana comparteix noves propostes programàtiques de cara a una possible renovació del seu govern.

En relació amb aquesta última dada, és significatiu que, dins dels missatges amb més likes, tant en el cas del PSPV-PSOE (18,18 \%) i de Compromís $(15,79 \%)$ com en el de Mónica Oltra (15,79 \%), els seguidors de Facebook han focalitzat una part important del seu interés en les publicacions centrades en els assoliments obtinguts per aquests partits polítics o per la líder (taules 4 i 5). Contràriament als seguidors dels partits en l'oposició, els seguidors dels actors polítics en el Govern se senten més interessats pels missatges en què es destaquen les me- sures i altres èxits que s'ha aconseguit complir en la legislatura anterior.

\section{Temes amb més likes entre els usuaris de Facebook i Instagram}

Pel que fa a la temàtica de les publicacions, les dades mostren que, dins del conjunt de missatges amb més likes, els usuaris de Facebook i Instagram segueixen un mateix patró i concentren la major part dels m'agrada en tres temàtiques: resultats electorals, política social i organització i funcionament de campanya. Una tendència que, en alguns casos, es veu influenciada per diferents factors rellevants.

En primer lloc, les publicacions centrades en els resultats electorals són aquelles que més likes han generat entre el públic de tots els perfils analitzats, a excepció dels del PP i Isabel Bonig. Una circumstància que, possiblement, es deu a la pèrdua de més de 150.000 vots i la reducció de 31 a 19 escons que ha patit el partit respecte de les eleccions autonòmiques de 2015. Per contra, si recalquem les diferències entre els usuaris de les dues xarxes socials analitzades, la temàtica dels resultats electorals influeix de manera rellevant en els seguidors de Facebook de Compromís (33,33 \%), Unides Podem (21,43\%), Vox (15,62 \%), Dalmau (17,86 \%) i Cantó (18,18 \%) (Taula 5). En Instagram, destaca l'interés que desperta aquesta qüestió en els perfils de Compromís (42,86\%), PSPV-PSOE $(35,29 \%)$, Ciudadanos (28,6 \%), Oltra $(57,14 \%)$ i Puig (30 \%), i és la segona temàtica a què els seguidors de Unides Podem (33,33 \%) i Dalmau (28,57 \%) han destinat més likes (Taula 6).

El segon tema que més reaccions ha generat és el de «Política social», present principalment en les publicacions de partits i líders tradicionals. Resulta significatiu que, tant els seguidors de Facebook i Instagram del PSPV-PSOE i el seu candidat com els de Bonig coincideixen a focalitzar la major part del seu interés en les publicacions sobre aquesta temàtica. L'ús, no obstant això, difereix significativament si es té en compte la posició que s'ocupa en el Govern. Mentre que les reaccions en els perfils del PSPV-PSOE i Puig es concentren en les publicacions que tracten qüestions socials des d'una òptica positiva, normalment 
Tabla 6 Temes de les publicacions en Facebook (en \%)

\begin{tabular}{|c|c|c|c|c|c|c|c|c|c|c|c|}
\hline Funció & PP & Bonig & $\begin{array}{l}\text { PSPV- } \\
\text { PSOE }\end{array}$ & Puig & Compr. & Oltra & $\begin{array}{l}\text { Unides } \\
\text { Podem }\end{array}$ & Dalmau & Cs & Cantó & Vox \\
\hline Economia & 7,69 & 14,29 & 4,55 & - & - & 15,79 & - & 10,71 & 9,09 & - & - \\
\hline Política social & 23,08 & 23,81 & 13,64 & 26,67 & 19,05 & 21,05 & - & 7,14 & 36,4 & - & 9,375 \\
\hline Cultura i esport & 3,85 & - & - & 6,67 & - & - & - & - & - & 9,09 & 3,125 \\
\hline $\begin{array}{l}\text { Ciència i } \\
\text { tecnologia }\end{array}$ & 3,85 & - & - & - & - & - & - & - & 9,09 & - & - \\
\hline Infraestructures & - & - & 4,55 & 6,67 & 4,76 & - & - & - & - & - & - \\
\hline Corrupció & 15,38 & - & - & - & 4,76 & 5,26 & - & 3,57 & 9,09 & - & 3,125 \\
\hline $\begin{array}{l}\text { Regeneració } \\
\text { democràtica }\end{array}$ & 7,69 & 14,29 & 4,55 & 26,67 & 4,76 & 10,53 & 64,29 & 21,43 & - & 9,09 & - \\
\hline $\begin{array}{l}\text { Joc i estratègia } \\
\text { política }\end{array}$ & 3,85 & 14,29 & 13,64 & 13,33 & 4,76 & 15,79 & - & 10,71 & 18,2 & 9,09 & - \\
\hline $\begin{array}{l}\text { Votació i } \\
\text { resultats } \\
\text { electorals }\end{array}$ & - & 14,29 & 13,64 & 13,33 & 33,33 & 10,53 & 21,43 & 17,86 & - & 18,18 & 15,62 \\
\hline $\begin{array}{l}\text { Model territorial } \\
\text { de l'Estat }\end{array}$ & - & - & - & - & 4,76 & - & 7,14 & - & - & 27,27 & 3,12 \\
\hline Terrorisme & - & - & - & - & - & - & - & - & - & 9,09 & 3,12 \\
\hline $\begin{array}{l}\text { Temes } \\
\text { personals }\end{array}$ & - & - & - & - & - & - & 7,14 & 7,14 & - & 9,09 & 6,25 \\
\hline $\begin{array}{l}\text { Organització de } \\
\text { campanya }\end{array}$ & 19,23 & 4,76 & 36,36 & 6,67 & 4,76 & 21,05 & - & 14,29 & 9,09 & 9,09 & 28,12 \\
\hline $\begin{array}{l}\text { Relació amb } \\
\text { els mitjans de } \\
\text { comunicació }\end{array}$ & 15,38 & 4,76 & - & - & - & - & - & - & - & - & 3,12 \\
\hline Sense tema & - & - & - & - & - & - & - & - & - & - & 9,37 \\
\hline Afers exteriors & - & 4,76 & - & - & 4,76 & - & - & - & - & - & - \\
\hline Arenga política & - & - & - & - & - & - & - & - & - & - & - \\
\hline Medi ambient & - & 4,76 & 9,09 & - & 14,29 & - & - & - & 9,09 & - & 12,5 \\
\hline Altres & - & - & - & - & - & - & - & - & - & - & 3,12 \\
\hline
\end{tabular}


relacionada amb els seus èxits polítics, les reaccions en el cas de Bonig són nombroses en les publicacions en què la candidata critica la falta de mesures o els fracassos del Govern en aquest àmbit (Figura 1).

Figura 1 Exemple de publicacions sobre política social

Isabel Bonig
El President de la Generalitat, Ximo Puig, todavía no haya dicho a los
valencianos de dónde piensa recortar 90 gos 1.500 millones de
euros que el Ministerio de Hacienda y el Gobierno de Sánchez le exigía
para que llegara el FLA a la Comunitat Valenciana. Recortará aún más en
Sanidad? en Dependencia? en Educación??
Hoy, ocho meses después de la llegada de Pedro Sánchez a la Moncloa el
President de la Generalitat, Ximo Puig, ha sido incapaz de reclamarle esa
nueva financiación ni un compromiso firme. No ha conseguido nada.
Ximo Puig Ferrer
25 de abril . 9
legislatura queremos acabar con la pobreza infantil y seguir atendiendo
problemas fundamentales como el desempleo y la violencia de género
\#SeguirSumando Las Provincias

Font: Facebook

En tercer lloc, el nombre de likes de les publicacions que giren entorn de l'organització de campanya està condicionat directament per l'eix col-lectiu-individual, de manera que n'hi ha més en el cas dels partits. Concretament, en els perfils d'Instagram del PP (58,33\%), Vox (42,86 \%) i Unides Podem (41,67 \%), pràcticament la meitat dels likes se centren en publicacions on la temàtica principal gira entorn de l'organització dels diferents actes electorals, l'elaboració de les llistes de candidats o altres aspectes relacionats amb la campanya. En Facebook, la quantitat de m'agrada en publicacions sobre aquest tema ha sigut menor que en Instagram, encara que en aquest sentit destaquen els perfils de PSPV (36,36\%), Vox $(28,12 \%)$ i Compromís (21,05 \%). Pel que fa als líders, solament les publicacions de Dalmau en Instagram han tingut una incidència important en les reaccions dels seus seguidors $(42,86 \%)$.
Paral-lelament al patró general observat en la temàtica de les publicacions amb més likes, són rellevants els casos de Unides Podem i de Cantó en Facebook, ja que els seguidors d'aquests perfils són els únics que s'han mostrat altament interessats per les temàtiques «Regeneració democràtica» $(64,29 \%) \mathrm{i}$ «Model territorial de l'Estat» $(27,27 \%)$, respectivament. Es tracta de missatges en què, d'una banda, es debat sobre la necessitat d'un canvi en el sistema polític actual i, de l'altra, sobre l'organització territorial de l'Estat. Aquestes publicacions es destinen, sobretot, a criticar l'actualitat entorn de la independència de Catalunya (Taula 6). Com a partit i líder emergent, han introduït aquest tipus de qüestions com una manera de diferenciar-se de la resta de partits polítics. Per això, els propis seguidors es mostren altament atrets per aquestes temàtiques.

\section{Recursos visuals amb més likes entre els usuaris de Facebook i Instagram}

Des de l'aparició i l'ús de les xarxes socials en el context de la comunicació política, aquestes s'han convertit en plataformes potents per a difondre imatges (Svensson i Russmann, 2017). Instagram està plantejada de manera que obliga que totes les publicacions hagen d'utilitzar un recurs visual, siga una imatge estàtica o un vídeo. No obstant això, en Facebook la utilització d'aquesta mena d'elements no és obligatòria per a fer una publicació. Per això, és significatiu que els usuaris d'aquesta última xarxa social hagen valorat especialment bé les que contenen aquest tipus de recursos. A excepció de Ciudadanos (18,18 \%), Vox $(31,25 \%)$ i PP $(34,61 \%)$, en tots els perfils, més de la meitat de les publicacions amb més likes contenen alguna fotografia, vídeo o un altre element visual (Taula 8).

Aquestes dades permeten afirmar que les reaccions dels usuaris de Facebook estan directament condicionades per l'eix col-lectiu-individual i per la posició que el partit polític i el líder ocupen en el Govern. D'una banda, els seguidors dels partits en el Govern són els que més reaccionen davant de les publicacions que contenen algun recurs visual. D'altra banda, les fotografies o vídeos emprats pels líders en l'oposició 
Taula 7 Temes de les publicacions en Instagram (en \%)

\begin{tabular}{|c|c|c|c|c|c|c|c|c|c|c|c|}
\hline Funció & PP & Bonig & $\begin{array}{l}\text { PSPV- } \\
\text { PSOE }\end{array}$ & Puig & Compr. & Oltra & $\begin{array}{l}\text { Unides } \\
\text { Podem }\end{array}$ & Dalmau & Cs & Cantó & Vox \\
\hline Economia & - & 5,88 & - & - & - & - & 8,33 & 14,29 & - & - & - \\
\hline Política social & 8,33 & 29,41 & 29,41 & 30 & 4,76 & 14,29 & - & - & 14,3 & - & 7,14 \\
\hline Cultura i esport & 16,67 & 5,88 & 5,88 & 10 & - & - & - & - & - & 33,33 & - \\
\hline $\begin{array}{l}\text { Ciència i } \\
\text { tecnologia }\end{array}$ & 8,33 & - & - & - & - & - & - & - & - & - & - \\
\hline Infraestructures & - & - & - & - & - & - & - & - & - & - & - \\
\hline Corrupció & - & - & - & - & - & - & - & - & - & - & - \\
\hline $\begin{array}{l}\text { Regeneració } \\
\text { democràtica }\end{array}$ & - & - & 5,88 & - & 23,81 & - & - & - & 14,3 & - & - \\
\hline $\begin{array}{l}\text { Joc i estratègia } \\
\text { política }\end{array}$ & - & 5,88 & - & 10 & 9,52 & - & 8,33 & - & 14,3 & - & 7,14 \\
\hline $\begin{array}{l}\text { Votació i resul- } \\
\text { tats electorals }\end{array}$ & 8,33 & 11,76 & 35,29 & 30 & 42,86 & 57,14 & 33,33 & 28,57 & 28,6 & 66,67 & 7,14 \\
\hline $\begin{array}{l}\text { Model territorial } \\
\text { de l'Estat }\end{array}$ & - & - & 5,88 & - & 4,76 & - & 8,33 & - & - & - & - \\
\hline Terrorisme & - & - & - & - & - & - & - & - & - & - & - \\
\hline Temes personals & - & - & - & - & - & - & - & - & 14,3 & - & - \\
\hline $\begin{array}{l}\text { Organització de } \\
\text { campanya }\end{array}$ & 58,33 & 11,76 & 17,65 & 10 & 4,76 & - & 41,67 & 42,86 & - & - & 42,86 \\
\hline $\begin{array}{l}\text { Relació amb } \\
\text { els mitjans de } \\
\text { comunicació }\end{array}$ & - & - & - & 10 & - & - & - & - & - & - & - \\
\hline Sense tema & - & 17,65 & - & - & - & 28,57 & - & 14,29 & - & - & 14,29 \\
\hline Afers exteriors & - & - & - & - & 4,76 & - & - & - & 14,3 & - & - \\
\hline Arenga política & - & - & - & - & - & - & - & - & 14,3 & - & - \\
\hline Medi ambient & - & 11,76 & - & - & 4,76 & - & - & - & - & - & 12,5 \\
\hline Altres & - & - & - & - & - & - & - & - & - & - & 3,12 \\
\hline
\end{tabular}

Font: Elaboració pròpia.

són els que han generat més interés entre els seus seguidors. Destaca el fet que totes o pràcticament totes les publicacions amb més reaccions de Cantó (100 \%) i Bonig (90,47 \%) contenen aquest tipus de recursos, la qual cosa demostra el rol preferent de la imatge en els perfils d'aquests dos candidats, així com la vinculació que tenen a la construcció del seu lideratge polític.
Quant a la tipologia de recursos visuals presents en les publicacions amb més likes, les dades revelen que mentre que la fotografia és l'element preferit en Instagram, el vídeo és el que més interés genera entre els seguidors de Facebook. En aquesta última xarxa social, difereixen únicament els seguidors de PP, Vox i Ximo Puig, en què les reaccions es focalitzen en les 
Taula 8 Publicacions amb més likes que contenen algun recurs visual en Facebook

\begin{tabular}{|l|l|l|l|}
\hline PSPV-PSOE & $81,81 \%$ & Puig & $53,33 \%$ \\
\hline Compromís & $90,47 \%$ & Oltra & $68,42 \%$ \\
\hline Unides Podem & $92,85 \%$ & Dalmau & $64,38 \%$ \\
\hline PP & $34,61 \%$ & Bonig & $90,47 \%$ \\
\hline Cs & $18,18 \%$ & Cantó & $100 \%$ \\
\hline Vox & $31,25 \%$ & & \\
\hline
\end{tabular}

Font: Elaboració pròpia. publicacions que contenen una fotografia (Taula 9). Ambdues plataformes coincideixen en l'interés nul que tenen els usuaris per altres tipus de recursos visuals com els selfies, els GIF, els mems o els muntatges fotogràfics. Únicament en el perfil de Facebook de Compromís (21,05 \%) o en el d'Instagram de Vox (21,43\%), cartells compostos per imatges amb textos de caràcter explicatiu han generat interés en els usuaris (Taula 9).

Taula 9 Tipus de recursos visuals que més likes han generat en Facebook i Instagram (en \%)

\begin{tabular}{|c|c|c|c|c|c|c|c|c|c|c|}
\hline Perfil & $\begin{array}{l}\text { Xarxa } \\
\text { social }\end{array}$ & Foto & Selfie & $\begin{array}{l}\text { Mun- } \\
\text { tatge }\end{array}$ & Mem & Vídeo & GIF & $\begin{array}{l}\text { Car- } \\
\text { tell }\end{array}$ & $\begin{array}{c}\text { Captura de } \\
\text { pantalla }\end{array}$ & $\begin{array}{c}\text { Gràfi- } \\
\text { ca }\end{array}$ \\
\hline \multirow[t]{2}{*}{ PSPV-PSOE } & FB & 33,33 & - & - & - & 50 & - & 16,67 & - & - \\
\hline & $I G$ & 58,82 & - & - & - & 35,29 & - & - & - & 5,88 \\
\hline \multirow[t]{2}{*}{ Compromís } & FB & 21,05 & - & - & 5,26 & 42,11 & - & 21,05 & 5,26 & 5,26 \\
\hline & $I G$ & 38,10 & - & 4,76 & - & 33,33 & - & 4,76 & 4,76 & 14,29 \\
\hline \multirow[t]{2}{*}{ Unides Podem } & $\mathrm{FB}$ & 84,61 & - & - & - & - & - & 7,69 & - & 7,69 \\
\hline & IG & 75 & - & - & - & 25 & - & - & - & - \\
\hline \multirow[t]{2}{*}{ PP } & $\mathrm{FB}$ & 66,67 & - & - & 11,11 & 22,22 & - & - & - & - \\
\hline & IG & 91,67 & - & - & - & 8,33 & - & - & - & - \\
\hline \multirow[t]{2}{*}{ Ciudadanos } & $\mathrm{FB}$ & - & - & - & - & 100 & - & - & - & - \\
\hline & $I G$ & 71,43 & - & - & - & 14,29 & - & - & - & - \\
\hline \multirow[t]{2}{*}{ Vox } & $\mathrm{FB}$ & 60 & - & - & 10 & 20 & - & 10 & - & - \\
\hline & $I G$ & 64,29 & - & 7,14 & - & 7,14 & - & 21,43 & - & - \\
\hline \multirow[t]{2}{*}{ Puig } & FB & 75 & - & - & - & 25 & - & - & - & - \\
\hline & $I G$ & 100 & - & - & - & - & - & - & - & - \\
\hline \multirow[t]{2}{*}{ Oltra } & $\mathrm{FB}$ & - & - & - & - & 100 & - & - & - & - \\
\hline & $I G$ & 71,43 & - & - & - & 28,57 & - & - & - & - \\
\hline \multirow[t]{2}{*}{ Dalmau } & $\mathrm{FB}$ & 33,33 & - & 5,55 & - & 44,44 & - & 11,11 & - & 5,55 \\
\hline & $I G$ & 100 & - & - & & - & - & - & - & - \\
\hline \multirow[t]{2}{*}{ Bonig } & FB & 36,84 & - & - & - & 52,63 & - & 10,52 & - & - \\
\hline & $I G$ & 76,47 & - & - & - & 23,53 & - & - & - & - \\
\hline
\end{tabular}


Pel que fa al contingut dels recursos visuals, les fotografies i els vídeos que mostren els candidats o algun altre membre de la formació oferint un míting són els que més interés generen entre els seguidors d'ambdues xarxes socials, especialment en el cas dels partits, en què, generalment, aquests recursos es troben en entorn del $50 \%$ de les publicacions amb més likes (Taula 10). Difereixen únicament Compromís (10,53 \% en Facebook i 28,57 \% en Instagram) i Unides Podem (23,08 \% en Facebook), els seguidors de la qual s'interessen també per continguts visuals que presenten els candidats o les candidates o altres membres del partit en un debat o depositant la seua papereta en les urnes (Taula 10). En el cas dels líders,

Taula 10 Context del recurs visual que més likes ha generat en Facebook i Instagram (en \%)

\begin{tabular}{|c|c|c|c|c|c|c|c|c|c|c|c|c|c|}
\hline \multirow[t]{2}{*}{ Perfil } & \multirow{2}{*}{$\begin{array}{l}\text { Xarxa } \\
\text { social }\end{array}$} & \multicolumn{3}{|c|}{ Personal } & \multicolumn{5}{|c|}{ Electoral } & \multicolumn{3}{|c|}{ Mediàtic } & \multirow{2}{*}{$\begin{array}{l}\text { Altres } \\
\text { Altres }\end{array}$} \\
\hline & & $\begin{array}{l}\text { Fa- } \\
\text { mília }\end{array}$ & Oci & $\begin{array}{l}\text { Back- } \\
\text { stage }\end{array}$ & $\begin{array}{l}\text { Mí- } \\
\text { ting }\end{array}$ & Visita & $\begin{array}{l}\text { De- } \\
\text { bat }\end{array}$ & $\begin{array}{l}\text { Es- } \\
\text { pot }\end{array}$ & $\begin{array}{l}\text { Vota- } \\
\text { ció }\end{array}$ & $\begin{array}{c}\text { En- } \\
\text { tre- } \\
\text { vista }\end{array}$ & $\begin{array}{l}\text { Roda } \\
\text { prem- } \\
\text { sa }\end{array}$ & $\begin{array}{l}\text { In } \\
\text { situ }\end{array}$ & \\
\hline \multirow{2}{*}{$\begin{array}{r}\text { PSPV- } \\
\text { PSOE }\end{array}$} & $\mathrm{FB}$ & - & - & - & 55,56 & - & 5,56 & 16,8 & 16,8 & - & - & - & 5,56 \\
\hline & $I G$ & - & - & - & 47,06 & 5,88 & - & 23,5 & 5,88 & - & 5,88 & 5,88 & 5,88 \\
\hline \multirow{2}{*}{$\begin{array}{r}\text { Com- } \\
\text { promís }\end{array}$} & $\mathrm{FB}$ & - & - & - & 10,53 & - & 26,32 & - & 26,32 & 5,26 & 10,53 & - & 21,05 \\
\hline & $I G$ & - & - & - & 28,57 & - & - & 4,76 & 9,52 & - & - & 4,76 & 52,38 \\
\hline \multirow{2}{*}{$\begin{array}{l}\text { Unides } \\
\text { Podem }\end{array}$} & $\mathrm{FB}$ & - & 7,69 & - & 23,08 & - & 23,08 & 15,4 & 23,08 & - & 7,69 & - & - \\
\hline & $I G$ & - & - & - & 41,67 & - & 16,67 & - & 33,33 & - & - & - & 8,33 \\
\hline \multirow[t]{2}{*}{ PP } & FB & - & - & - & 44,44 & 22,22 & 11,11 & 11,1 & 11,11 & - & - & - & - \\
\hline & $I G$ & - & - & - & 66,67 & 33,33 & - & - & - & - & - & - & - \\
\hline \multirow{2}{*}{$\begin{array}{l}\text { Ciuda- } \\
\text { danos }\end{array}$} & FB & - & - & - & - & - & 50 & 50 & - & - & - & - & - \\
\hline & $I G$ & - & 14,3 & - & 42,86 & 14,29 & 14,29 & - & 14,29 & - & - & - & - \\
\hline \multirow[t]{2}{*}{ Vox } & FB & - & - & - & 60 & - & - & - & 10 & - & - & - & 30 \\
\hline & $I G$ & - & - & - & 42,86 & - & - & - & 7,14 & - & - & - & 50 \\
\hline \multirow[t]{2}{*}{ Puig } & FB & - & - & - & 50 & 12,5 & 12,5 & - & 25 & - & - & - & - \\
\hline & $I G$ & - & - & - & 30 & 10 & - & - & 20 & 10 & - & - & 30 \\
\hline \multirow[t]{2}{*}{ Oltra } & FB & - & - & - & 38,46 & - & 38,46 & 7,69 & 7,69 & - & - & - & 7,69 \\
\hline & $I G$ & - & - & 28,57 & - & - & 14,29 & 28,6 & - & - & - & - & 14,29 \\
\hline \multirow{2}{*}{$\begin{array}{l}\text { Dal- } \\
\text { mau }\end{array}$} & FB & 5,55 & 5,55 & 5,55 & 22,22 & 11,11 & 22,22 & - & 16,66 & - & - & - & 11,11 \\
\hline & $I G$ & - & - & - & 28,57 & 28,57 & - & - & 28,57 & 14,29 & - & - & - \\
\hline \multirow[t]{2}{*}{ Bonig } & $\mathrm{FB}$ & - & - & - & 36,84 & 21,05 & 15,78 & 10,5 & - & - & - & 10,52 & 5,26 \\
\hline & IG & - & - & - & 52,82 & 11,76 & 17,65 & 5,88 & - & - & - & - & 5,88 \\
\hline \multirow[t]{2}{*}{ Cantó } & FB & - & - & 9,09 & - & - & 18,18 & - & 18,18 & 18,18 & - & - & 36,36 \\
\hline & $I G$ & - & 33,3 & - & - & - & - & - & 66,67 & - & - & - & - \\
\hline
\end{tabular}


els likes en imatges de mítings són nombrosos en els perfils de Bonig i de Puig en totes dues xarxes socials (Taula 10). En el cas d'Oltra, Dalmau i Cantó les reaccions a aquesta mena de recursos es redueixen.

En ambdues xarxes socials es pot observar que els recursos visuals de contingut personal encara generen un interés baix en els usuaris. Les poques reaccions que aquests vídeos o fotografies produeixen es concentren en els perfils de Unides Podem, Ciudadanos, Dalmau, Cantó i Oltra. Així mateix, els continguts visuals es troben principalment en les publicacions on els líders comparteixen les seues aficions o el backstage de campanya. Només en el cas de Dalmau alguns usuaris reaccionen davant de publicacions en què apareix junt amb la seua família (Figura 2). Per tant, s'adverteix que, tot i que de manera incipient, els seguidors d'aquests partits i líders estan començant a valorar els continguts en què aquests actors polítics comparteixen la seua vida personal amb la intenció de crear una relació més pròxima i estreta amb l'electorat.

Un altre aspecte important en relació amb els continguts visuals és el protagonista. En tots els perfils estudiats, l'interés dels seguidors es concentra en tres tipus de recursos segons l'actor principal: fotografies $\mathrm{o}$ vídeos en què només apareix el líder autonòmic $\mathrm{o}$ el líder autonòmic amb altres membres del partit, o es mostra el líder nacional sol o acompanyat pel candidat o candidata autonòmica. No obstant això, el nombre de likes que han rebut aquests continguts en cada perfil es veu condicionat per diferents factors.

En primer lloc, els recursos visuals usats en les publicacions on només apareix el líder autonòmic han tingut una repercussió rellevant en els perfils dels propis líders, independentment de la posició que tinga en el Govern, la trajectòria o la ideologia. En aquest sentit, és significatiu l'interés mostrat pels seguidors d'Instagram d'Oltra (42,86 \%) i Cantó $(66,67 \%)$, perfils en què entorn de la meitat de les publicacions els exposen com a protagonistes. De fet, aquests dos casos, així com el d'Oltra en Facebook, són els únics en què les imatges dels líders
Figura 2 Exemple de publicacions personals
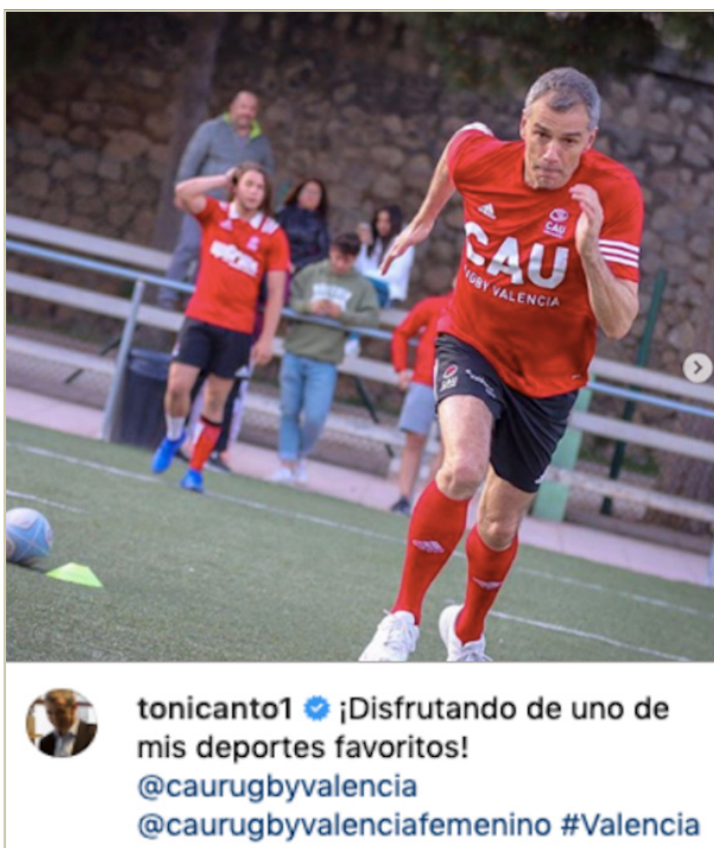

Rubén Martínez Dalmau está aquí: Port De Xàbia.

28 de abril . Jávea . 6

La família i els candidats municipals votant en Xàbia. En Xàbia també es pot!

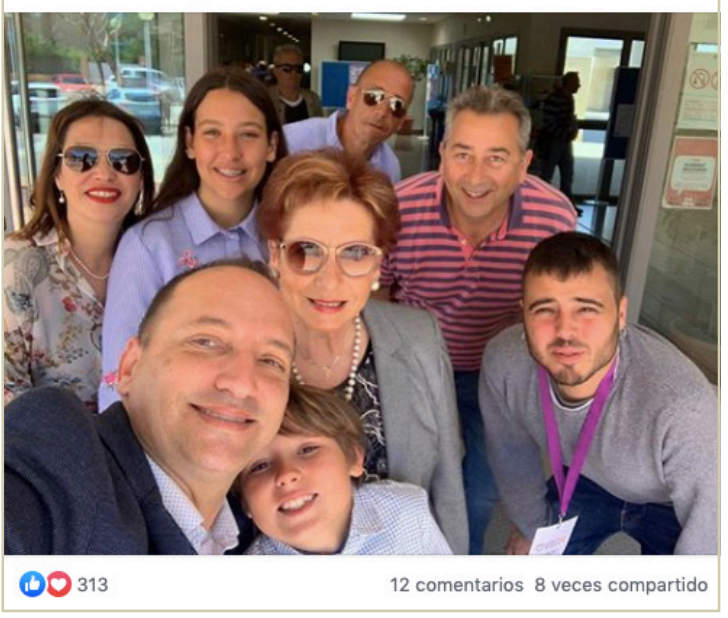

Font: Instagram i Facebook 
Figura 3 Publicacions amb més likes segons el protagonista del recurs visual

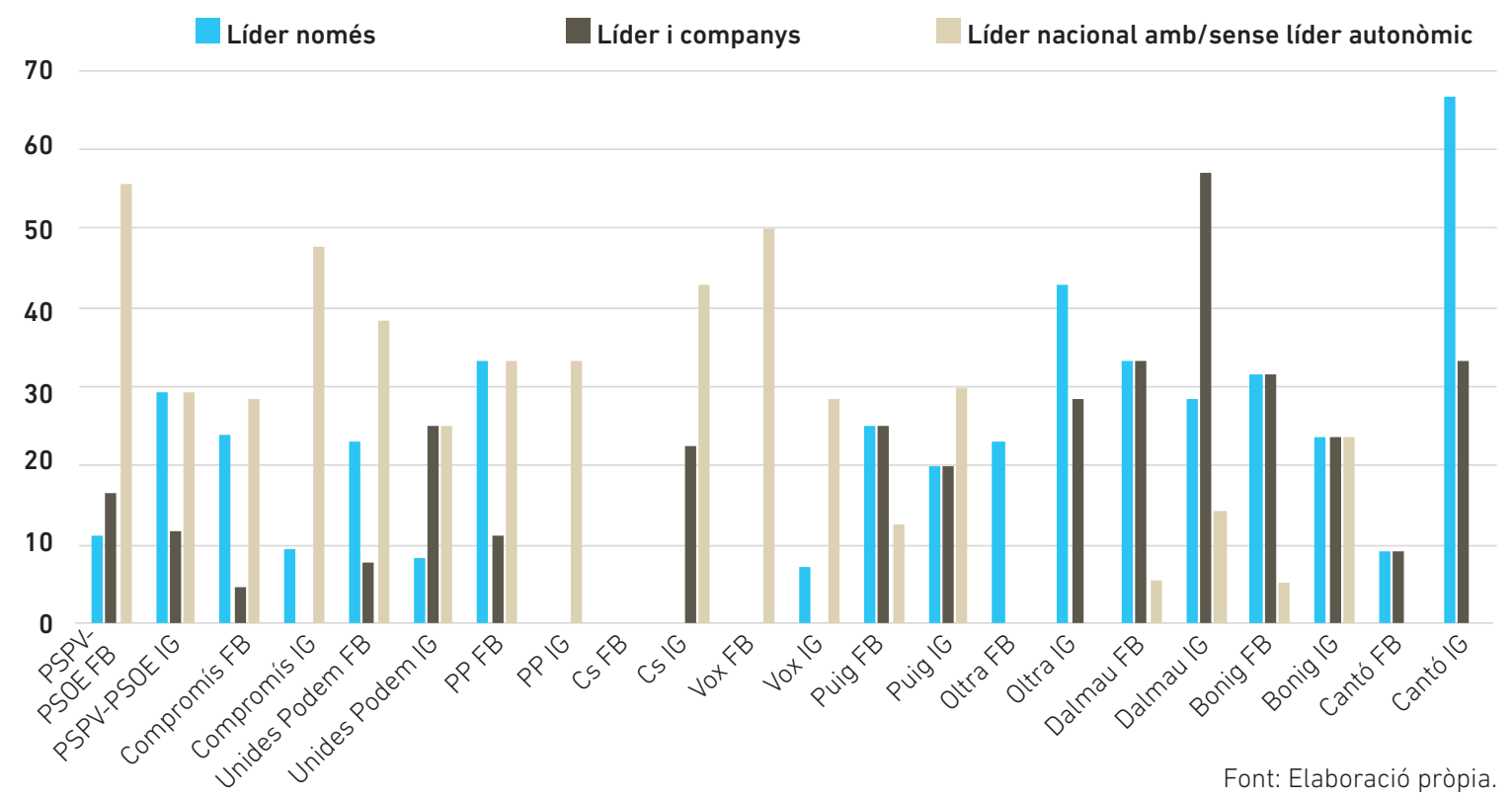

autonòmics han tingut més interés entre els usuaris que les imatges on apareixen acompanyats per altres companys o pel líder nacional (Figura 3).

Quant a l'impacte que tenen els continguts visuals que mostren els líders autonòmics acompanyats per altres membres del partit, s'observa, de nou, una incidència més alta en els perfils dels candidats (Figura 3). És rellevant el cas de Dalmau, en què aquest tipus d'imatges o vídeos superen pel doble aquelles en què només apareix ell com a candidat autonòmic (57,14 \% enfront del 28,57 \%). Les dades demostren, així, que els seguidors del líder de Unides Podem reaccionen significativament davant d'aquells recursos en els quals es mostra una imatge de partit unit $\mathrm{i}$ no només el líder com a referent.

Finalment, en els continguts visuals que protagonitzen els líders nacionals sols o acompanyats dels autonòmics, el nombre de reaccions augmenta, principalment en els perfils dels partits polítics (Figura 3). La presència d'aquests recursos destaca tant en partits tradicionals com el PSPV-PSOE (55,55 \% en Facebook) o Compromís (47,62 \% en Instagram), com en formacions emergents com Cs $(42,86 \%$ en Instagram) o Vox (50 \% en Facebook). Quant als líders, aquests continguts visuals únicament han generat un interés rellevant entre els usuaris en el perfil d'Instagram de Puig (30 \%) (Figura 3). D'aquesta manera, les dades revelen que, mentre que els seguidors dels líders autonòmics reaccionen més significativament davant de les imatges o vídeos en què els polítics són el focus central, els seguidors dels partits tendeixen a sentir-se més atrets per les figures dels candidats nacionals, fet que demostra la centralitat $i$ influència que té la seua imatge.

\section{Recursos d'interacció amb més likes entre els usuaris de Facebook i Instagram}

Tant Facebook com Instagram ofereixen diverses fórmules que afavoreixen la comunicació bidireccional. Les més reconegudes són les mencions, els hashtags i els enllaços, que potencien la creació de vincles entre els diversos usuaris, afavoreixen la 
interactivitat i permeten ampliar la informació respecte d'un tema o qüestió. Malgrat la utilitat comuna que tenen, les dades afirmen que l'ús en les publicacions dels diferents actors polítics genera un interés dispar en els usuaris de totes dues xarxes socials.

D'aquesta manera, els missatges que han inclòs una menció o més no són determinants en l'obtenció de likes, ja que a penes han cridat l'atenció dels usuaris. Destaca únicament el cas de Toni Cantó en Instagram, en què el 66,67 \% de les publicacions que inclouen aquest recurs ha generat un nombre rellevant de reaccions per part dels usuaris.

Per contra, el recurs que ha resultat més atractiu per als usuaris és el hashtag. A excepció del perfil de

Taula 11 Presència de recursos d'interacció en els posts amb més likes de Facebook i Instagram

\begin{tabular}{|c|c|c|c|c|c|c|c|}
\hline \multirow[t]{2}{*}{ Perfil } & \multirow{2}{*}{$\begin{array}{l}\text { Xarxa } \\
\text { social }\end{array}$} & \multicolumn{2}{|c|}{ Menció } & \multicolumn{2}{|c|}{ Hashtag } & \multicolumn{2}{|c|}{ Enllaç } \\
\hline & & Sí & No & Sí & No & Sí & No \\
\hline \multirow[t]{2}{*}{ PSPV-PSOE } & FB & 9,09 & 90,91 & 27,27 & 72,73 & 31,82 & 68,18 \\
\hline & INST & 35,29 & 64,70 & 83,35 & 17,64 & - & - \\
\hline \multirow[t]{2}{*}{ Compromís } & FB & 9,52 & 90,48 & 14,29 & 85,71 & 33,33 & 66,67 \\
\hline & IG & 28,57 & 71,42 & 90,47 & 9,52 & 19,05 & 80,95 \\
\hline \multirow[t]{2}{*}{ Unides Podem } & FB & 7,14 & 92,86 & 28,57 & 71,43 & 7,15 & 92,87 \\
\hline & IG & 33,33 & 66,67 & 100 & - & - & 100 \\
\hline \multirow[t]{2}{*}{ PP } & $\mathrm{FB}$ & 15,38 & 84,62 & 46,15 & 53,85 & 69,23 & 30,77 \\
\hline & IG & 33,33 & 66,67 & 100 & - & - & 100 \\
\hline \multirow[t]{2}{*}{ Ciudadanos } & $\mathrm{FB}$ & 18,18 & 81,82 & 9,09 & 90,91 & 81,82 & 18,18 \\
\hline & IG & 18,57 & 71,43 & 100 & - & - & 100 \\
\hline \multirow[t]{2}{*}{ Vox } & $\mathrm{FB}$ & 12,50 & 87,50 & 37,50 & 62,50 & 68,75 & 31,25 \\
\hline & IG & 28,57 & 71,43 & 85,71 & 14,29 & - & 100 \\
\hline \multirow[t]{2}{*}{ Puig } & $\mathrm{FB}$ & 13,33 & 86,67 & 40 & 60 & 46,67 & 53,33 \\
\hline & IG & 20 & 80 & 60 & 40 & - & 100 \\
\hline \multirow[t]{2}{*}{ Oltra } & FB & 10,53 & 89,47 & 15,79 & 84,21 & 36,84 & 63,18 \\
\hline & IG & 28,57 & 71,43 & 42,86 & 57,14 & - & 100 \\
\hline \multirow[t]{2}{*}{ Dalmau } & $\mathrm{FB}$ & 3,57 & 93,43 & 14,29 & 85,71 & 35,71 & 64,29 \\
\hline & IG & 14,29 & 85,71 & 54,14 & 42,86 & - & 100 \\
\hline \multirow[t]{2}{*}{ Bonig } & $\mathrm{FB}$ & 19,05 & 80,95 & 57,14 & 42,86 & - & 100 \\
\hline & IG & 23,53 & 76,47 & 70,59 & 29,41 & - & 100 \\
\hline \multirow[t]{2}{*}{ Cantó } & FB & 18,18 & 81,82 & 9,09 & 90,91 & - & 100 \\
\hline & IG & 66,67 & 33,33 & 33,33 & 66,67 & - & 100 \\
\hline
\end{tabular}


Facebook de Ciudadanos (9,09 \%), Cantó (9,09 \%), Compromís (14,29 \%) i Dalmau (14,29 \%), la reacció dels usuaris davant de les publicacions que contenen aquest recurs és significativament alta en tots els perfils dels actors polítics analitzats. Destaquen, sobretot, els casos de l'Instagram de Unides Podem, Cs i PP, en els quals aquest recurs es troba present en el $100 \%$ de les publicacions que han cridat més l'atenció entre els usuaris (Taula 11).

Finalment, l'ús d'enllaços per part de partits polítics i candidats també ha generat una important quantitat de m'agrada entre el públic, tot i que en menor mesura que els hashtags. A excepció del perfil de Unides Podem en Instagram (7,15\%), en totes les publicacions d'aquesta xarxa social on apareix aquest recurs, el percentatge de likes es troba entre el $32 \%$ i el $69 \%$ (Taula 11), la qual cosa demostra que els usuàris l'han acceptat.

Quant a la naturalesa dels enllaços, destaca que, independentment de l'actor polític, la major part d'aquests es dirigeixen a pàgines web de mitjans de comunicació. El 100 \% dels enllaços publicats per Cs, PP, Unides Podem, Bonig i Dalmau es dirigeixen a pàgines web de periòdics, programes televisius $\mathrm{o}$ radiofònics o agències de notícies, el contingut de les quals es relaciona directament amb el partit, el candidat o algun altre membre de la formació. El percentatge és menor en Compromís $(42,85 \%)$, PSPV-PSOE $(42,85 \%)$, Vox $(77,27 \%)$, Puig $(85,71 \%)$ i Oltra $(84,74 \%)$. Tanmateix, en aquests perfils, els enllaços es dirigeixen o bé a altres xarxes socials del partit o a xarxes d'altres membres de la formació, com en els casos de Compromís, Vox, PSPV-PSOE i Puig, o bé a les pàgines web del partit, com en el cas d'Oltra. Aquestes dades assenyalen, per tant, la importància que els usuaris atorguen als mitjans de comunicació convencionals i el rol central que aquests continuen ocupant en la comunicació política en campanya electoral, fins i tot en l'entorn digital. Així, encara que els usuaris han passat a utilitzar les xarxes socials per a informar-se i difondre la seua opinió, mantenen un fort interés pels continguts publicats per diaris, televisions o ràdios.

\section{CONCLUSIONS}

Els resultats de l'estudi assenyalen quatre grans aportacions que permeten conéixer quins elements presents en les publicacions dels actors polítics reuneixen més likes entre els usuaris de Facebook i Instagram durant la campanya electoral.

En relació amb la PI1, les dades demostren que, en general, en ambdues xarxes socials les publicacions de partits i líders polítics que comparteixen informació d'agenda o propostes programàtiques coincideixen a reunir una quantitat important de m'agrada. En concordança amb la literatura prèvia, que indica un ús habitual de les xarxes socials per part dels actors polítics per a difondre informació electoral (Magin et al., 2017; López-Meri et al., 2017), s'observa també un interés alt dels usuaris per aquest tipus de continguts.

En resposta a la PI2, els resultats assenyalen que la posició que ocupa el partit i el líder en el Govern resulta determinant en el nombre de likes. D'una banda, els seguidors dels actors polítics de l'oposició reaccionen significativament davant d'aquelles publicacions en què aquests critiquen o ataquen els seus adversaris, sobretot, els que estan en el Govern. Mostrant el seu interés per aquest tipus de publicacions, aquests usuaris reafirmen el seu descontentament enfront de les mesures i la gestió del Govern autonòmic. D'altra banda, els seguidors dels partits en el Govern es decanten pels missatges en els quals s'enalteixen les mesures i els èxits polítics que han aconseguit durant la legislatura més que per l'ús d'atacs cap a altres partits rivals. D'aquesta manera, els usuaris empren les xarxes socials com un canal per mitjà del qual donar suport als partits i als líders que segueixen, als quals presten el seu suport mitjançant els likes per potenciar la difusió dels seus missatges. De la mateixa manera, una altra funció que reuneix un alt nombre de m'agrada en els partits i candidats en el Govern és la de participació, amb la qual fomenten la implicació dels usuaris en els diferents actes electorals i destaquen els valors i la ideologia del projecte polític, de manera que els electors puguen sentir-se identificats com a part d'una comunitat (Giansante, 2015; Casero-Ripollés, 2018). 
Una segona contribució rellevant assenyala que els usuaris de Facebook i Instagram es mostren altament interessats per tres tipus de temàtiques: política social, resultats electorals i organització de campanya (PI1). Els seguidors d'aquests actors polítics i, especialment, els dels partits tradicionals, reaccionen de manera notable davant de publicacions sobre educació, sanitat i altres drets socials. Una dada que demostra la seua preocupació per la gestió d'aquelles qüestions que els afecten directament com a ciutadans i ciutadanes. Paral-lelament, gran part dels usuaris reacciona davant de temes relacionats directament amb la campanya electoral, com ara els resultats de les votacions o l'organització dels diferents actes electorals. Aquest fet, igual que en el cas de les funcions, demostra que els usuaris senten un interés especial per aspectes relacionats amb el funcionament de la campanya electoral, principalment per informacions sobre actes a què poden assistir i on poden veure els líders o altres membres del partit. Per contra, únicament en perfils de partits i líders emergents com Unides Podem, Dalmau o Cantó temàtiques com la regeneració democràtica o el model territorial de l'Estat han generat una repercussió notable entre els usuaris (PI2).

Una tercera aportació d'aquesta investigació posa de manifest que la quantitat de likes dels usuaris és rellevant en les publicacions que inclouen recursos visuals (PI1), d'acord amb allò que indica la literatura prèvia (Viounnikoff-Benet, 2018; Svensson i Russmann, 2017; Fenoll i Hassler, 2019). Mentre que els usuaris d'Instagram mostren un interés especial per les fotografies, les publicacions que comparteixen vídeos són les que generen més impacte en Facebook. Al contrari, recursos habituals en aquestes xarxes socials com els selfies, mems o GIF tenen una incidència pràcticament nul-la en la reacció dels usuaris. Així mateix, els continguts visuals que mostren un rol professional dels candidats, per exemple oferint un míting, participant en un debat o fent una visita oficial, tenen més impacte en els usuaris que els continguts que exposen una faceta més personal o humana. Una tendència que contradiu allò assenyalat per la literatura prèvia, que indica que l'ús d'imatges que mostren aspectes de la vida privada dels actors polítics permet potenciar la connexió amb els usuaris (Selva Ruíz i Caro Castanyer, 2017).

Finalment, la quarta troballa suggereix que, en relació amb els recursos d'interacció, les mencions no resulten útils per a cridar més l'atenció dels usuaris, la qual cosa difereix d'allò que apunten investigacions anteriors (Larsson, 2015). Per contra, aquests recursos amb prou feines aconsegueixen una repercussió significativa entre els usuaris. Mentrestant, les publicacions que contenen hashtags i les que contenen enllaços sí que tenen una incidència rellevant entre els usuaris (Miquel Segarra et al., 2017). En relació amb aquesta tendència, els resultats revelen, a més, que, d'acord amb allò que indiquen treballs previs, els usuaris d'aquestes xarxes socials continuen atorgant un paper preferent als mitjans de comunicació convencionals (Chadwick, 2013). En aquest sentit, la major part dels enllaços que més likes han generat es dirigeixen a continguts publicats per diaris, televisions o ràdios (PI1), fet que demostra que els usuaris combinen el potencial de l'entorn digital amb la lògica dels mitjans convencionals (Casero Ripollés et al., 2016).

\section{REFERÈNCIES BIBLIOGRÀFIQUES}

Abejón, P., Sastre, A. i Linares, V. (2012). Facebook y Twitter en campañas electorales en España. Disertaciones: Anuario electrónico de estudios en Comunicación Social, 5(7), 129-159.

Abejón Mendoza, P. i Mayoral Sánchez, J. (2017). Persuasión a través de Facebook de los candidatos en las elecciones generales de 2016 en España. El profesional de la información, 26(5), 928-936. DOI: 10.3145/epi.2017.sep.14 
Alonso Muñoz, L. i Casero Ripollés, A. (2018). Political Agenda on Twitter during the 2016 Spanish Elections: Issues, Strategies, and Users' Responses. Communication \& Society, 31(3), 7-25.

Alonso Muñoz, L., Marcos García, S. i Casero Ripollés, A. (2016). Political Leaders in (inter)Action: Twitter as a Strategic Communication Tool in Electoral Campaigns. Trípodos, 39, 71-90.

Bentivegna, S. (2015). A colpi di tweet: La politica in prima persona. Bolonya: Il Mulino.

Casero Ripollés, A. (2018). Research on Political Information and Social Media: Key Points and Challenges for the Future. El profesional de la información, 27(5), 964-974. DOI: 10.3145/epi.2018.sep.01

Casero Ripollés, A., Feenstra, R. A. i Tormey, S. (2016). Old and New Media Logics in an Electoral Campaign: The Case of Podemos and the Ttwo-way Street Mediatization of Politics. The International Journal of Press/Politics, 21(3), 378-397. DOI: 10.1177/1940161216645340

Castillejo, B. i Semova, D. (2012). Elecciones generales y redes sociales en el caso de España, 2011. International Review of Information Ethics, 18, 144-149.

Cebrián Guinovart, E., Vázquez, T. i Olbarrieta, A. (2013). ¿Participación y democracia en los medios sociales? El caso de Twitter en las elecciones vascas de 2012. adComunica, 6, 39-63.

Chadwick, A. (2013). The Hybrid Media System: Politics and Power. Nova York: Oxford University Press. DOI: 10.1093/ acprof:oso/9780199759477.001.0001

Christensen, H. S. i Bengtsson, Å. (2011). The Political Competence of Internet Participants: Evidence from Finland. Information, Communication \& Society, 14(6), 896-916. DOI: 10.1080/1369118X.2011.566931

Coromina, O., Prado, E. i Padilla, A. (2018). The Grammatization of Emotions on Facebook in the Elections to the Parliament of Catalonia 2017. El profesional de la información, 27(5), 1004-1011. DOI: 10.3145/epi.2018.sep.05

Díaz, J. B. (2014). Polarización política en las redes sociales. El caso español en el canal de comunicación Twitter. Estudio del debate del estado de la nación 2013. En A. R. Fernández Paradas (coord.), Interactividad y redes sociales (p. 95-114). Madrid: ACCI.

Di Bonito, I. (2014). El uso de Facebook durante las campañas electorales: Reflexiones sobre las elecciones catalanas de 2010 y 2012. Revista de la Asociación Española de Investigadores en Comunicación, 1(1), 26-34.

Enli, G. i Skogerbø, E. (2013). Personalized Campaigns in Party-centred Politics: Twitter and Facebook as Arenas for Political Communication. Information, Communication \& Society, 16(5), 757-774. DOI: $10.1080 / 1369118 X .2013 .782330$

Fenoll, V. i Cano Orón, L. (2017). Participación ciudadana en los perfiles de Facebook de los partidos españoles: Análisis de comentarios en la campaña electoral de 2015. Communication \& Society, 30(4), 131-148.

Fenoll, V. i Hassler, J. (2019). ¿La red de los populistas? Diferencias en la campaña electoral en Facebook de España y Alemania. IC Revista Científica de Información y Comunicación, 16, 451-484. DOI: 10.12795/IC.2019.i19.14

Fernández Muñoz, C. i Arceo Vacas, A. (2015). El papel de las redes sociales en la campaña electoral de los principales candidatos municipales y autonómicos madrileños en 2011: Claves desde el punto de vista de la comunicación de las organizaciones. Prisma Social, Revista de Ciencias Sociales, 14, 29-57.

Filimonov, K., Russmann, U. i Svensson, J. (2016). Picturing the Party: Instagram and Party Campaigning in the 2014 Swedish Elections. Social Media + Society, 2(3).

García, A., García, I. i Varona, D. (2012). Incidencia de las redes sociales vs. Cibermedios en las elecciones en España, 2011. Enl@ce: Revista Venezolana de Información, Tecnología y Conocimiento, 9(2), 11-29.

Gamir Ríos, J. V. (2016). Difusión online de las agendas partidistas en campaña electoral: El uso de internet en las elecciones locales de 2015 en la ciudad de Valencia (Tesi doctoral). Universitat de València, Comunitat Valenciana.

Giansante, G. (2015). La comunicación política online. Barcelona: Editorial UOC.

Hootsuite (2019). Digital 2019: Global Digital Overview (2019). Recuperat de https://datareportal.com/reports/ digital-2019-q2-global-digital-statshot.

Igartua, J. J. (2006). Métodos cuantitativos de investigación en comunicación. Barcelona: Bosh.

Jenkins, H. (2006). Convergence Culture: Where Old and New Media Collide. Nova York: NYU Press.

Jungherr, A. (2014). The Logic of Political Coverage on Twitter: Temporal Dynamics and Content. Journal of Communication, 64(2), 239-259.

Kreiss, D. (2012). Taking our Country back: The Crafting of Networked Politics from Howard Dean to Barack Obama. Nova York: Oxford University Press. 
Kruikemeier, S. (2014). How Political Candidates Use Twitter and the Impact on Votes. Computers in Human Behavior, 34, 131-139.

Larsson, A. O. (2015). Comparing to Prepare: Suggesting Ways to Study Social Media Today and Tomorrow. Social Media Society, 1(1).

Lilleker, D. G., Tenscher, J. i Štetka, V. (2015). Towards Hypermedia Campaigning? Perceptions of New Media's Importance for Campaigning by Party Strategists in Comparative Perspective. Information, Communication \& Society, 18(7), 747-765.

López García, G. (2016). "Nuevos” y “viejos” liderazgos: La campaña de las elecciones generales españolas de 2015 en Twitter. Communication \& Society, 29(3), 149-167.

López García, G., Cano Orón. L. i Argilés Martínez, L. (2016). Circulación de los mensajes y establecimiento de la agenda en Twitter: El caso de las elecciones autonómicas de 2015 en la Comunidad Valenciana. Trípodos, 39, 163-183.

López Meri, A. (2016). Twitter-retórica para captar votos en campaña electoral: El caso de las elecciones de Cataluña de 2015. Comunicación y Hombre, 12, 97- 118.

López Meri, A., Marcos García, S. i Casero Ripollés, A. (2017). What Do Politicians Do on Twitter? Functions and Communication Strategies in the Spanish Electoral Campaign of 2016. El profesional de la información, 26(5), 795-804. DOI: 10.3145/epi.2017.sep.02

López Rabadán, P. i Doménech Fabregat, H. (2018). Instagram y la espectacularización de las crisis políticas: Las 5W de la imagen digital en el proceso independentista de Cataluña. El profesional de la información, 27(5), 1013-1029. DOI: $10.3145 /$ epi.2018.sep.06

López Rabadán, P., López Meri, A. i Doménech Fabregat. (2016). La imagen política en Twitter. Usos y estrategias de los partidos políticos españoles. Index Comunicación, 6(1), 165-195.

Magin, M., Podschuweit, N., Haßler, J. i Russmann, U. (2017). Campaigning in the Fourth Age of Political Communication. A Multi-method Study on the Use of Facebook by German and Austrian Parties in the 2013 National Election Campaigns. Information, Communication \& Society, 20(11), 1698-1719. DOI: 10.1080/1369118X.2016.1254269

Mancini, P. (2013). Media Fragmentation, Party System, and Democracy. The International Journal of Press/Politics, 18(1), 43-60. DOI: 10.1177/1940161212458200

Marcos García, S. i Alonso Muñoz, L. (2017). La gestión de la imagen en campaña electoral. El uso de Instagram por parte de los partidos y líderes españoles en el 26J. En J. Sierra Sánchez, S. Liberal Ormaechea, (coord.), Uso y aplicación de las redes sociales en el mundo audiovisual y publicitario (p. 107-118). Madrid: McGraw-Hill.

Marcos García, S. i Alonso Muñoz, L. (2019). ¿Elecciones del cambio? Gestión estratégica de Twitter en los comicios municipales de Madrid 2015. En C. C. Flores Pérez, A. I. Arévalo Salinas i A. Barranquero Carretero, A. (ed.), Comunicación, cultura de paz e igualdad: Tejiendo ciudadanía comunicativa (p. 70-80). Zacatecas (Mèxic): Universidad Autónoma de Zacatecas.

Marcos García, S., Alonso Muñoz, L. i Casero Ripollés, A. (2017). Usos ciudadanos de Twitter en eventos políticos relevantes: La \#SesiónDeInvestidura de Pedro Sánchez. Comunicación y Hombre, 13, 25-49.

McNair, B. (2011). An Introduction to Political Communication. Nova York: Routledge Taylor \& Francis.

Micó, J. L. i Casero Ripollés, A. (2014). Political Activism Online: Organization and Media Relations in the Case of $15 \mathrm{M}$ in Spain. Information, Communication \& Society, 17(7), 858-871. DOI: 10.1080/1369118X.2013.830634

Miquel Segarra, S., Alonso Muñoz, L. i Marcos García, S. (2017). Buscando la interacción: Partidos y candidatos en Twitter durante las elecciones generales de 2015. Prisma Social, 18, 34-54.

Morozov, E. (2011). The Net Delusion: How not to Liberate the World. Londres: Penguin Books.

Parmelee, J. H. i Bichard, S. L. (2011). Politics and the Twitter Revolution: How Tweets Influence the Relationship between Political Leaders and the Public. Lexington Books.

Pérez, J. A., Peña, S., Genaut, A., Iturregui, L. i Mendiguren, T. (2014). Comunicación política en internet: Estrategias online de los partidos políticos vascos en las elecciones autonómicas de 2009. Mediateka, 14, 125-150.

Quevedo Redondo, R. i Portalés Oliva, M. (2017). Imagen y comunicación política en Instagram. Celebrificación de los candidatos a la presidencia del Gobierno. El profesional de la información, 26(5), 916-927. DOI: 10.3145/epi.2017. sep. 13 
Quevedo Redondo, R., Portalés Oliva, M. i Berrocal Gonzalo, S. (2016). El uso de la imagen en Twitter durante la campaña electoral municipal de 2015 en España. Revista Latina de Comunicación Social, 71, 85-107. DOI: 10.4185/ RLCS-2016-1085

Rahat, G. i Sheafer, T. (2007). The Personalization(s) of Politics: Israel, 1949-2003. Political Communication, 24(1), 65-80.

Rúas Araújo, X. i Casero Ripollés, A. (2018). Comunicación política en la época de las redes sociales: Lo viejo y lo nuevo, y más allá. adComunica. Revista Científica de Estrategias, Tendencias e Innovación en Comunicación, 16, 2124. DOI: 10.6035/2174-0992.2018.16.2

Selva Ruiz, D. i Caro Castaño, L. (2017). Uso de Instagram como medio de comunicación política por parte de los diputados españoles: La estrategia de humanización en la "vieja" y la "nueva" política. El profesional de la Información, 26(5), 903-915. DOI: 10.3145/epi.2017.sep.12

Stromer Galley, J. (2014). Presidential Campaigning in the Internet Age. Nova York: Oxford University Press.

Svensson, J. i Russmann, U. (2017). Introduction to Visual Communication in the Age of Social Media: Conceptual, Theoretical and Methodological Challenges. Media \& Communication, 5(4), 1-5. DOI: 10.17645/mac.v5i4.1263

Vaccari, C. (2017). Online Mobilization in Comparative Perspective: Digital Appeals and Political Engagement in Germany, Italy, and the United Kingdom. Political Communication, 34(1), 69-88. DOI: 10.1080/10584609.2016.1201558.

Viounnikoff-Benet, N. (2018). La imagen del candidato en la era digital: Cómo gestionar la escenografía política. Editorial UOC: Barcelona.

Zugasti Azagra, R. i Pérez González, J. (2016). Los temas de campaña en Twitter de @PPopular y @ahorapodemos para las elecciones europeas de 2014. adComunica. Revista Científica de Estrategias, Tendencias e Innovación en Comunicación, 12, 205-223. DOI: 10.6035/2174-0992.2016.12.12.

\section{NOTA BIOGRÀFICA}

\section{Silvia Marcos García}

Professora ajudant doctora a la Universitat Jaume I de Castelló. Doctora en Ciències de la Comunicació, graduada en Periodisme i màster en Noves Tendències i Processos d'Innovació en Comunicació per la Universitat Jaume I. El seu treball s'emmarca en l'estudi del periodisme i la comunicació política en l'àmbit de les xarxes socials.

\section{Nadia Viounnikoff-Benet}

Doctora en Ciències de la Comunicació per la Universitat Jaume I de Castelló. És llicenciada en Publicitat i Relacions Públiques i màster en Gestió de la Comunicació Política i Electoral per la Universitat Autònoma de Barcelona. El seu treball se centra en l'estudi de la narrativa visual del lideratge polític en campanya electoral.

\section{Andreu Casero Ripollés}

Catedràtic d'universitat de Periodisme i degà de la Facultat de Ciències Humanes i Socials de la Universitat Jaume I. És llicenciat per la Universitat Autònoma de Barcelona i doctor per la Universitat Pompeu Fabra. Les seues línies d'investigació se centren en la comunicació política i en les transformacions digitals del periodisme. És membre de l'Institut d'Estudis Catalans.

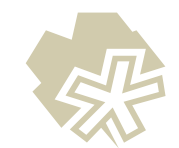

